\title{
Modeled distribution and abundance of a pelagic seabird reveal trends in relation to fisheries
}

\author{
Martin Renner ${ }^{1,5, *}$, Julia K. Parrish ${ }^{1}$, John F. Piatt ${ }^{2}$, Kathy J. Kuletz ${ }^{3}$, \\ Ann E. Edwards ${ }^{1,4}$, George L. Hunt, Jr. ${ }^{1}$ \\ ${ }^{1}$ School of Aquatic and Fishery Sciences, University of Washington, Box 351800, Seattle Washington 98195, USA \\ ${ }^{2}$ US Geological Survey, Alaska Science Center, 4210 University Drive, Anchorage, Alaska 99508, USA \\ ${ }^{3}$ Migratory Bird Management, US Fish and Wildlife Service, 1011 E. Tudor Rd., Anchorage, Alaska 99503, USA \\ ${ }^{4}$ Alaska Fisheries Science Center, NOAA, REFM Division, 7600 Sand Point Way NE, Seattle, Washington 98115, USA
}

${ }^{5}$ Present address: Tern Again Consulting, 388 E. Bayview Ave., Homer, Alaska 99603, USA

\begin{abstract}
The northern fulmar Fulmarus glacialis is one of the most visible and widespread seabirds in the eastern Bering Sea and Aleutian Islands. However, relatively little is known about its abundance, trends, or the factors that shape its distribution. We used a long-term pelagic dataset to model changes in fulmar at-sea distribution and abundance since the mid-1970s. We used an ensemble model, based on a weighted average of generalized additive model (GAM), multivariate adaptive regression splines (MARS), and random forest models to estimate the pelagic distribution and density of fulmars in the waters of the Aleutian Archipelago and Bering Sea. The most important predictor variables were colony effect, sea surface temperature, distribution of fisheries, location, and primary productivity. We calculated a time series from the ratio of observed to predicted values and found that fulmar at-sea abundance declined from the 1970s to the 2000s at a rate of $0.83 \%( \pm 0.39 \% \mathrm{SE})$ per annum. Interpolating fulmar densities on a spatial grid through time, we found that the center of fulmar distribution in the Bering Sea has shifted north, coinciding with a northward shift in fish catches and a warming ocean. Our study shows that fisheries are an important, but not the only factor, shaping fulmar distribution and abundance trends in the eastern Bering Sea and Aleutian Islands.
\end{abstract}

KEY WORDS: Aleutian Islands · Bering Sea $\cdot$ Distribution shifts · Fisheries · Fulmarus glacialis · Habitat modeling $\cdot$ Population trend

\section{INTRODUCTION}

The northern fulmar Fulmarus glacialis is one of the most abundant and widespread seabirds of the Bering Sea and Aleutian Islands. Organisms that are easy to sample (such as seabirds) can serve as indicators of changes in the ecosystem on which they depend, responding with changes in abundance (Cury et al. 2011) and/or changes in distribution (e.g. Fisher 1952). Over the last $40 \mathrm{yr}$, the Bering Sea ecosystem has undergone considerable change (Coyle et al. 2011, Hunt et al. 2011). The management of fisheries there has also changed, with both a reduction in the bycatch of seabirds and a reduction in the amount of fish waste discharged by fishing vessels (NMFS 2004). Here, we use a habitat model to ask what factors shape fulmar distribution in the Bering Sea and Aleutian Islands, and how the pelagic distribution and abundance of fulmars there may have changed since the mid-1970s. In particular, we relate changes in the distribution and abundance of fulmars to changes in fisheries practices in the eastern Bering Sea.

Beyond the Bering Sea, the northern fulmar is also found in the North Pacific and North Atlantic Oce- 
ans. Since the 1700 s, the North Atlantic fulmar population has expanded dramatically in size and distribution. Two major sources of variation in the pelagic habitats occupied by fulmars are climate variability (which affects the marine food webs on which fulmars depend), and commercial fishing (which may have positive impacts via the provision of food, and negative impacts via mortality of birds caught in fishing gear). Both northern and southern Fulmarus glacialoides fulmars have been shown to be sensitive to climate variation (Thompson \& Ollason 2001, Jenouvrier et al. 2003), and it has been hypothesized that the North Atlantic fulmar population increase was a result of the abundance of supplementary food from fishing and whaling operations (Fisher 1952, Burg et al. 2003). There are no comparable historical data from the North Pacific Ocean, and even the present-day North Pacific fulmar population size is poorly known.

Our study focused on fulmars in the eastern Bering Sea and Aleutian Islands regions. Fulmar foraging trips during chick rearing are usually within $500 \mathrm{~km}$ of the colony (Weimerskirch et al. 2001), and breeding fulmars from the Bering Sea and Aleutian Islands spend most of their time within the Bering Sea region, with a few venturing farther south into the North Pacific and into Russian coastal waters during winter (Hatch et al. 2010). We therefore assumed that once colony location was accounted for, the pelagic distribution of fulmars in the Bering Sea and Aleutian Islands would provide an indication of the availability of their preferred prey, and changes in fulmar distribution and abundance over time would reveal changes in the Bering Sea/Aleutian Islands' ecosystem on which they depend.

\section{Bering Sea and climate change}

The Bering Sea is subject to climate variability over a wide variety of temporal scales (Stabeno et al. 2001) and is expected to be an area of rapid change as human-induced climate warming progresses (IPCC 2007). For example, over the past $35 \mathrm{yr}$, there have been major changes in the amount of seasonal sea ice present in the Bering Sea and the timing of its retreat in spring (Stabeno \& Overland 2001, Overland \& Stabeno 2004). In the northern Bering Sea, there is evidence that spring seaice retreat has already advanced significantly, and that this change is impacting the amount and fate of primary production there (Grebmeier et al. 2006). Similarly, over the southeastern Bering Sea shelf, the timing of sea ice retreat has been shown to affect the timing and fate of the spring bloom and its ability to support pelagic and benthic fish and shellfish resources (Hunt et al. 2002b, 2008, 2011, Orensanz et al. 2005, Mueter \& Litzow 2008). Resulting changes in the distribution, abundance or availability of prey have been shown to affect the distribution, abundance, productivity, and survival of seabirds (e.g. Anderson \& Piatt 1999, Baduini et al. 2001, Hunt et al. 2002a, 2008, Jahncke et al. 2005b, 2008, Byrd et al. 2008, Benowitz-Fredericks et al. 2008).

\section{Food from fisheries}

Like many other seabird species, fulmars are attracted to fishing vessels because they provide an abundant source of food (Garthe \& Scherp 2003, Furness et al. 2007). Fisheries discharges offer an alternative food source to the natural diet and, as such, have the potential to open up previously unsuitable habitat, increase reproductive performance, and reduce the likelihood of starvation (Tasker et al. 2000, Montevecchi 2002). Although direct observations have suggested that fishing vessels have only a local $(<10 \mathrm{~km})$ effect on the distribution of fulmars at sea (Skov \& Durinck 2001), satellite tracking has revealed large-scale alterations in the foraging behavior of shearwaters in the Mediterranean Sea when fishing vessels were operational (Bartumeus et al. 2010).

The extent to which fulmars in the Pacific feed on fishery discharge, however, is unclear. The natural diet of fulmars in areas with little or no fisheries consists largely of zooplankton (Phillips et al. 1999, Jahncke et al. 2005a), although live fish are also taken and may be an important part of the diet (Cherel et al. 2001). In the North Atlantic, in spite of the presence of large fisheries, fulmars have been shown to respond to climate change (Thompson \& Ollason 2001), and the actual importance of fishery discharges, even in an area as heavily fished as the North Sea, has been called into question (Camphuysen \& Garthe 1997, Phillips et al. 1999).

Over the past 4 decades there have been major changes in the management of Bering Sea and Aleutian Islands fisheries. Legislative efforts have since 1977 focused on reducing the bycatch of non-target fish species and increasing the proportional use of each fish caught, resulting in a reduction of discharges. Since 1975, water quality regulations of the US Environmental Protection Agency (40CFR408) have mandated that, with a few exceptions, all onshore and at-sea processing facilities within the ex- 
clusive economic zone (EEZ) must macerate all discharges (discards and offal) into pieces no greater than $1 / 2$ inch in diameter. At least in some cases, maceration may increase food availability to seabirds (Furness et al. 2007). Because changes in fisheries practices in the Bering Sea coincided closely with changes in the Bering Sea climate, identification of their respective contributions to changes in fulmar populations is a challenge.

\section{Fulmars killed as bycatch}

Accidental bycatch of seabirds in trawl and longline fisheries is a major global conservation concern (Melvin \& Parrish 2001). Procellariiformes are especially vulnerable, with most albatross species now being classified as threatened, endangered, or critically endangered (BirdLife International 2008). Fulmars are the most common seabird species taken in Alaskan groundfish fisheries, with an average of 6500 birds killed annually between 1993 and 2004 (NMFS 2006). While this number is fairly small compared to the total Alaskan population of fulmars (estimated from colony counts to be around 1.5 million birds; Hatch 1993, Hatch \& Nettleship 1998), fulmars commonly venture into international and Russian waters, especially in winter (Hatch et al. 2010). Estimating the size of the bycatch is especially difficult in those regions (Lewison \& Crowder 2003), though recent information suggests that the bycatch of seabirds in the Russian Far East off the Kamchatka Peninsula is similar in magnitude to their bycatch mortality in Alaskan waters (Artyukhin et al. 2006, Anderson et al. 2011). Even small decreases in adult survival rates can lead to long-term declines in longlived species (Weimerskirch \& Jouventin 1987, Croxall et al. 1990, Tuck et al. 2001). Thus, with the general uncertainties about the total population size, the lack of fulmar population trend data, and a lack of comprehensive information on fishery bycatch Pacific-wide, concerns regarding at least localized effects on Alaska fulmar populations have been raised (see Hatch et al. 2010).

\section{Objectives}

In this study, we sought not only to detect and describe changes in the pelagic distribution and abundance of fulmars, but also to examine whether we could relate any changes detected to either the effects of climate or the effects of changing commer- cial fishing practices. We reasoned that if fulmars are primarily dependent on 'natural' prey such as zooplankton, changes in climate known to impact lower trophic levels should also affect these seabirds ('climate hypothesis'). Under the climate hypothesis, we would predict that fulmar distribution should show a fit with environmental variables related to trophic production. Likewise, if climate structures fulmar population dynamics, we would predict that fulmar populations should fluctuate with decadal-scale climate indices such as the Aleutian Low Pressure Index or North Pacific Gyre Oscillation (Di Lorenzo et al. 2008). By contrast, if fulmars depend to a large degree on fishery discharges, they should respond to variations in the distribution and quantity of catches of the Bering Sea fishing fleets ('fisheries hypothesis'). Under the fisheries hypothesis, we would expect the distribution of fishing activities to be a good predictor of fulmar distribution. We would also expect fulmar populations to respond to changes in fishery regulations, especially those affecting discards and bycatch.

\section{MATERIALS AND METHODS}

\section{Study area and time periods covered}

We bounded the study area by the Bering Strait in the north, the 200 nautical mile zone of the EEZ in the west and south, and the $159^{\circ} \mathrm{W}$ meridian in the east; this area comprises about 2.33 million $\mathrm{km}^{2}$ (Fig. 1) and closely corresponds to the National Marine Fisheries Service reporting areas for the Bering Sea and Aleutian Islands (NMFS 2006). We chose this area because it has been well surveyed for pelagic seabirds and covers most of the fulmar breeding distribution in the North Pacific Ocean. We excluded the Russian part of the Bering Sea because we found no comparable data on fishery activities, and there was relatively light seabird survey coverage there. Our study area contains most of the fulmar colonies in the North Pacific, including the globally largest colony of the species (Fig. 1).

We further restricted our dataset by date from 1 May to 7 September, coinciding with the fulmar pre-breeding and breeding seasons, and thereby avoiding migrants and sea ice (arrival at colonies is between March in the south and May in the north; Hatch \& Nettleship 1998) and the influx of fledglings (earliest reported fledging date from Alaska is 8 September; Hatch \& Nettleship 1998). Survey coverage was also most comprehensive during these months. 


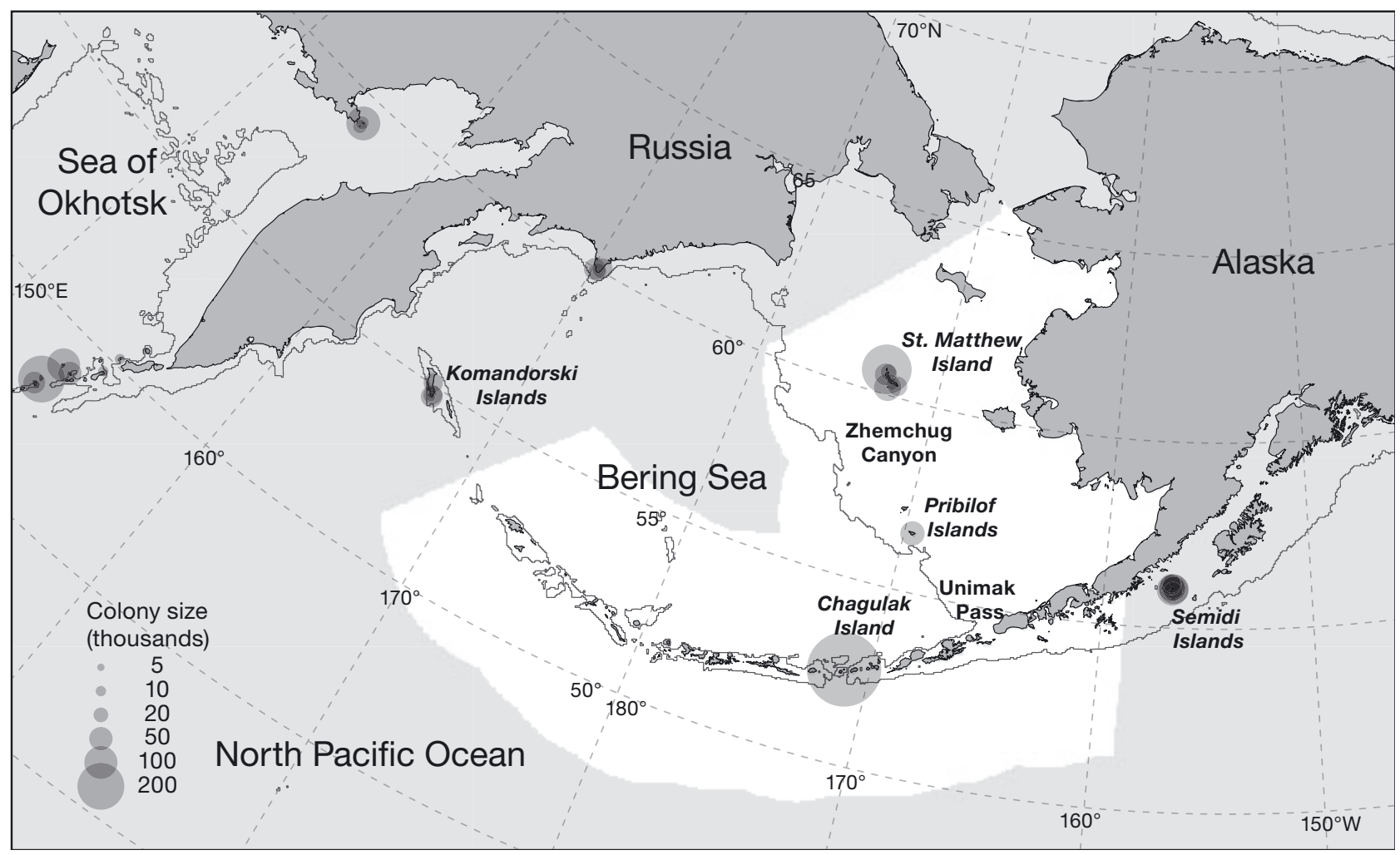

Fig. 1. Fulmarus glacialis. Study area: the Bering Sea and Aleutian parts of the Alaskan Exclusive Economic Zone (white). Also shown are the $400 \mathrm{~m}$ isobath (marking the edge of the continental shelf) and the colonies of northern fulmar

The northern half of the study area may be affected by seaice until early June, but few pelagic seabird surveys were conducted during May and June in the northern Bering Sea. The incorporation of monthly sea surface temperature into our distribution model should also address the issue of sea ice (see 'Modeling at-sea distribution and abundance').

\section{Data sources, survey methods and correction factors}

We combined pelagic seabird data from 5 principal data sources: (1) The North Pacific Pelagic Seabird Database (NPPSD; Drew \& Piatt 2005), (2) pelagic seabird surveys conducted by G.L.H. and co-workers on process studies from the 1980s to the 2000s, (3) surveys around major seabird colonies of the Alaska Maritime National Wildlife Refuge (Byrd et al. 1997, Renner et al. 2008), (4) North Pacific Research Board (NPRB)-funded ships of opportunity project (Sydeman et al. 2010), and (5) the current pelagic seabird project run by K.J.K. on ships of opportunity, also with support from NPRB. All of these data sources have undergone QA/QC procedures for archiving in the NPPSD. For the analysis here, we excluded aerial surveys and surveys without a defined transect width contained within the NPPSD. For additional information on the datasets and data collection methods used in the NPPSD, see publications employing NPPSD data e.g. Springer et al. 1999, Piatt \& Springer 2003, Hunt et al. 2005, Piatt et al. 2006, Renner et al. 2008, Drew et al. 2010.

Pelagic seabird surveys prior to 1984 were recorded by hand on paper forms in pre-defined time bins, usually of $10 \mathrm{~min}$ duration. In later years (but still using the same basic methods of data collection), data were entered directly into a computer continuously with a time-stamp and GPS positions for each observation of a seabird. These records did not have a pre-imposed bin length. We divided computerentered data into $3 \mathrm{~km}$ bins, equivalent to $10 \mathrm{~min}$ on a vessel traveling at 9 to 10 knots. At least since the late 1990s, geographic position fixes have been obtained exclusively from GPS, replacing positioning using Loran-C. Position errors of Loran-C are assumed to be less than $500 \mathrm{~m}$ and GPS fixes are accurate to less than $100 \mathrm{~m}$.

All surveys used standard strip transect methods, usually with a strip width of $300 \mathrm{~m}$, and counted all 
birds on the water or feeding (Tasker et al. 1984). Two different methods for counting flying birds were used. Most surveys in the 1970s and 1980s counted all flying birds observed within the transect strip. Beginning in the 1980s, many surveys used the snapshot method (Tasker et al. 1984), which was adopted by most investigators by the 2000s. The 'snapshot' is a method designed to eliminate the bias introduced by birds flying fast compared to the usually slowmoving survey vessel. Flying birds are counted at a set instant in time in a survey box (typically $300 \times$ $300 \mathrm{~m}$ ) and again when the vessel has passed over this virtual box. Consequently, the snapshot method does not count every flying bird seen (as in 'all flying birds'), but provides an estimate of the density of flying birds at sea that is not biased by the relative motion of the bird with respect to the ship, as is the case when all flying birds are counted (see Tasker et al. 1984).

The bias in surveys not employing the snapshot method (or equivalent corrections) depends on the bird's flying speed (which differs for each species), wind velocity, and wind direction in relation to that of the survey vessel (Spear et al. 1992). To meld datasets collected using these different survey methods, we divided the number of flying birds in a sample by a correction factor $\lambda_{m}$ when the snap-shot method was not used. Lacking empirical data for northern fulmar flight speeds, we used the value $\lambda_{\mathrm{m}}=2.3$ reported by van Franeker (1994) for the southern fulmar, an allopatric sibling-species of similar size and flying habits. To ensure that our analysis results were not driven by this correction factor, we also ran the same analyses with the minimal theoretically possible value of $\lambda_{\mathrm{m}}=1$ and with $\lambda_{\mathrm{m}}=5.0$, the highest value reported by van Franeker (1994). The $\lambda_{\mathrm{m}}=5.0$ was found for black-browed albatross Thalassarche melanophrys, a larger and considerably faster-flying species than the northern fulmars (especially in the conditions of the Southern Ocean). Since the correction factor increases with flying speed (Spear et al. 1997b), we are confident that the true correction factor is covered within these limits.

Densities and resulting at-sea population estimates reported here can be affected by other factors as well, including sea conditions, weather (rain, fog), observer skill, ship attraction, etc. (van der Meer \& Camphuysen 1996). However, given a large sample size, reasonable population estimates, and therefore estimates of population trends, can be obtained from at-sea data (Spear et al. 1995, van der Meer \& Leopold 1995, Clarke et al. 2003). We have no reason to suspect that the biases introduced by these factors have been sub- ject to long-term change and therefore would not affect trend estimates of fulmar densities. Nonetheless, we recognize that our analysis suffers from several uncorrected biases. Reported estimates of at-sea densities should be viewed with this in mind.

\section{Modeling at-sea distribution and abundance}

Survey coverage was heterogeneous, but large sample sizes were obtained in every year (Table 1). While some areas were sampled extensively and in most years, other areas were surveyed only once, if at all. Since survey effort was occasionally focused in a subset of the study area, any observed spatial pattern could be based on differences in spatial coverage,

Table 1. Fulmarus glacialis. Sample sizes (number of 10 min or $3 \mathrm{~km}$ bins), total area surveyed and number of bins in which northern fulmars were detected for each year of the study

\begin{tabular}{|c|c|c|c|}
\hline Year & $\mathrm{n}$ & Area $\left(\mathrm{km}^{2}\right)$ & $\mathrm{N}($ fulmar $>0)$ \\
\hline 1975 & 1085 & 1646 & 606 \\
\hline 1976 & 1300 & 1675 & 651 \\
\hline 1977 & 1174 & 1396 & 921 \\
\hline 1978 & 1919 & 1983 & 1399 \\
\hline 1979 & 850 & 835 & 510 \\
\hline 1980 & 1012 & 978 & 508 \\
\hline 1981 & 2286 & 2122 & 1715 \\
\hline 1982 & 2328 & 2528 & 1623 \\
\hline 1983 & 1571 & 1467 & 1186 \\
\hline 1984 & 882 & 1165 & 487 \\
\hline 1985 & 972 & 919 & 651 \\
\hline 1986 & 841 & 722 & 507 \\
\hline 1987 & 863 & 757 & 717 \\
\hline 1988 & 806 & 712 & 731 \\
\hline 1989 & 1003 & 803 & 763 \\
\hline 1990 & 317 & 288 & 225 \\
\hline 1991 & 629 & 566 & 282 \\
\hline 1992 & 1557 & 1352 & 1131 \\
\hline 1993 & 1521 & 1333 & 1261 \\
\hline 1994 & 1269 & 1084 & 342 \\
\hline 1995 & 1039 & 934 & 754 \\
\hline 1996 & 199 & 172 & 112 \\
\hline 1997 & 2483 & 1664 & 1449 \\
\hline 1998 & 2455 & 1983 & 1357 \\
\hline 1999 & 2884 & 2384 & 1497 \\
\hline 2000 & 123 & 162 & 118 \\
\hline 2001 & 604 & 461 & 497 \\
\hline 2002 & 1669 & 1270 & 763 \\
\hline 2003 & 747 & 556 & 418 \\
\hline 2004 & 2081 & 1469 & 1342 \\
\hline 2005 & 898 & 758 & 602 \\
\hline 2006 & 6608 & 4895 & 2825 \\
\hline 2007 & 11598 & 8216 & 4632 \\
\hline 2008 & 11808 & 6175 & 7025 \\
\hline 2009 & 13746 & 7395 & 7948 \\
\hline
\end{tabular}


unless differences in spatial coverage were accounted for by modeling. The heterogeneity of survey coverage also meant that not all portions of the study area received survey coverage in proportion to their areas in each time period. To compare observations in a particular year to an expected mean, we employed a spatial model of expected densities to compensate for the uneven survey coverage in space and time.

A schematic overview of our modeling approach is given in Fig. 2. To build a predictive model of the fulmar distribution in the Bering Sea and Aleutian Archipelago, we gathered a suite of raw and derived environmental and anthropogenic variables (Table 2, Fig. 3). All spatial data were projected into an Albers Equal Area projection with standard parameters for Alaska. We chose variables which we considered likely to be related to fulmar distribution at sea, and which were readily available. We assumed that most of these variables are not of direct importance to fulmars, but rather influence the distribution or nearsurface availability of potential prey. For example, steep underwater slopes can upwell prey to the surface (Ladd et al. 2005), but only if the slopes are not too deep (Jahncke et al. 2005a). We used the slope of the log of bathymetry because by doing so, we emphasized the importance of slope in shallow over slope in deep water.
Distance from the colony (Colony effect) could be thought of as the default distribution for seabird densities at sea during the breeding season (Ashmole \& Ashmole 1967). If the ocean environment was uniform without aggregations of prey, we would expect terrestrial, social, and random factors to determine the location and size of colonies. Due to geometric spreading (Kinder et al. 1983, Decker \& Hunt 1996), we would expect that at-sea density of fulmars $(F)$ at any given point $(p)$ will be related to the distance from the colony. Combining n colonies, we postulate that this effect would be additive over all colonies, leading to the expected at-sea density of fulmars at any given point to be proportional to the size $(s)$ of the colony $i$ and the inverse of the point's distance $(d)$ from the colony $i$ :

$$
F_{p} \propto \sum_{i=1}^{i=n} \frac{s_{i}}{d_{p, i}}
$$

Assuming that a pelagic species such as a fulmar would be reluctant to fly over land other than to reach its nest, we did not use the Euclidean distance but rather the shortest distance over water. As a starting point, we used the point on shore closest to any given colony (Fig. 1). We included the contribution of all North Pacific fulmar colonies, even those outside the study area.

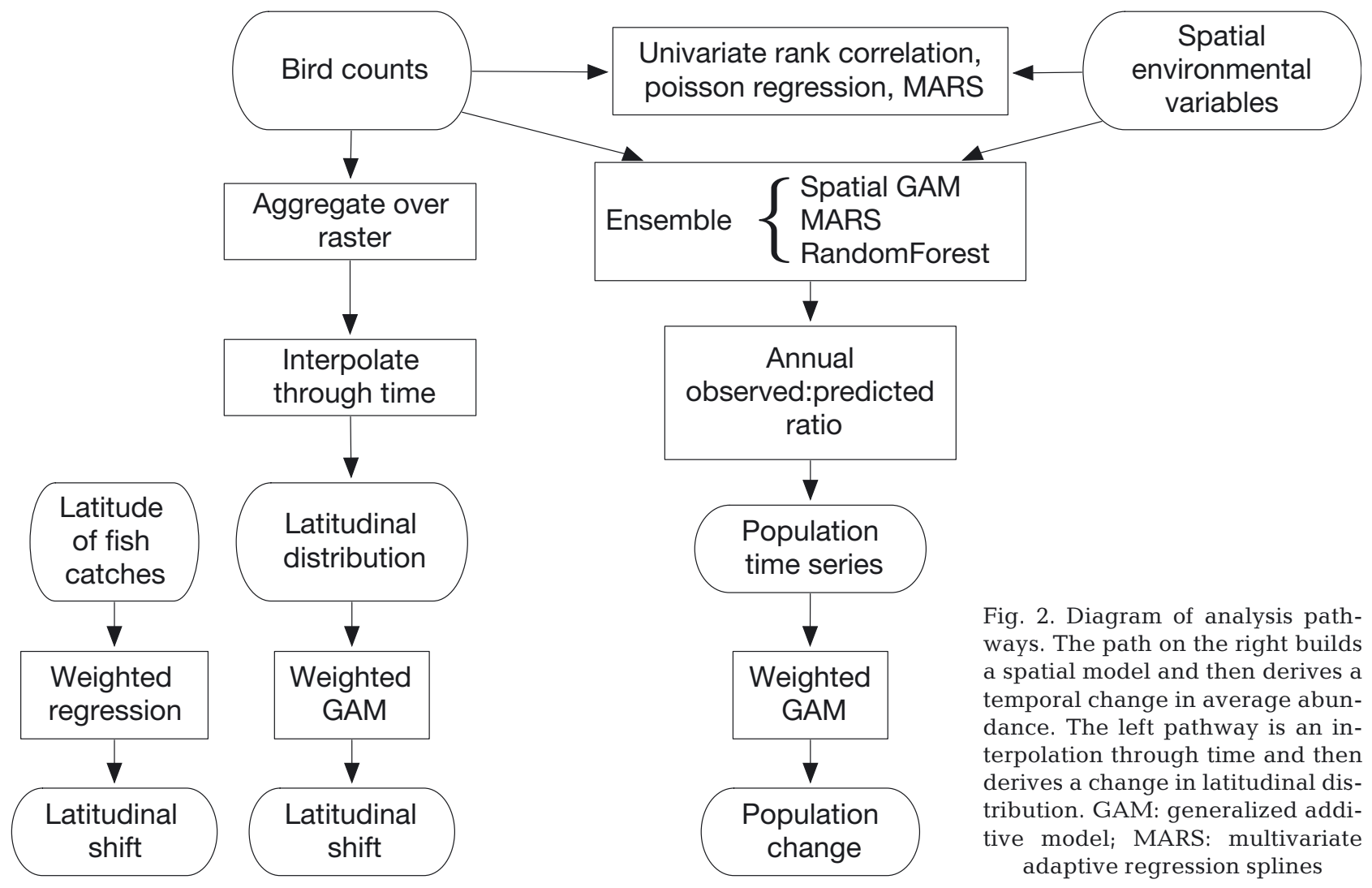


Table 2. Data sources and abbreviations for seascape variables used to model northern fulmar Fulmarus glacialis distribution. Since our dataset goes back to 1975, we used long-term averages (climatologies) for variables which change through time (i.e. SST and pprod). SST was the only variable for which we took the month of sampling into account

\begin{tabular}{|c|c|c|c|c|}
\hline Variable name & Abbreviation & Explanation & $\begin{array}{l}\text { Resolution } \\
\quad(\mathrm{km})\end{array}$ & Source \\
\hline Bathymetry & bathy & $\begin{array}{l}\text { Ocean depth interpolated from actual sounding } \\
\text { and satellite-derived gravity data on a } 30^{\prime} \text { grid }\end{array}$ & $<0.9$ & $\mathrm{GEBCO}^{\mathrm{a}}$ \\
\hline Slope of bathymetry & bathySl & First spatial derivative of bathymetry & 5 & \\
\hline Slope of log-bathymetry & $\log \mathrm{BaSl}$ & $\begin{array}{l}\text { As bathymetry slope but derived from the log } \\
\text { of bathymetry }\end{array}$ & 5 & \\
\hline Bathymetric features & baFeat & $\begin{array}{l}\text { Plains, ridges, channels, peaks and pits in the } \\
\text { log of bathymetry }\end{array}$ & 5 & Wood (1996) \\
\hline Distance to land & dLand & Distance to the nearest land & 5 & gshhs shoreline ${ }^{b}$ \\
\hline Colony effect & colony & $\begin{array}{l}\text { Expected distribution assuming even dispersal } \\
\text { from colonies (see Eq. 1) }\end{array}$ & 5 & $\begin{array}{l}\text { Beringian Seabird } \\
\text { Colony Catalog }\end{array}$ \\
\hline Sea surface temperature & SST & $\begin{array}{l}\text { 1985-2001 monthly average, derived from } \\
\text { AVHRR satellite }\end{array}$ & 4 & $\mathrm{NOAA}^{\mathrm{d}}$ \\
\hline Primary productivity & pprod & $\begin{array}{l}\text { Averaged May to September, 2002-2009, derived } \\
\text { from MODIS and Sea-WIFS ocean color and } \\
\text { temperature }\end{array}$ & 5 & OSU $^{\mathrm{e}}$ \\
\hline Fish catch & fishCatch & Haul size of all fisheries combined & 10 & NOAA $^{\mathrm{f}}$ \\
\hline \multicolumn{5}{|c|}{${ }^{a}$ www.bodc.ac.uk//data/online_delivery/gebco/ } \\
\hline \multicolumn{5}{|c|}{${ }^{b}$ www.soest.hawaii.edu/wessel/gshhg/ } \\
\hline \multicolumn{5}{|c|}{ chttp://alaska.fws.gov/mbsp/mbm/northpacificseabirds/colonies/default.htm } \\
\hline \multicolumn{5}{|c|}{ 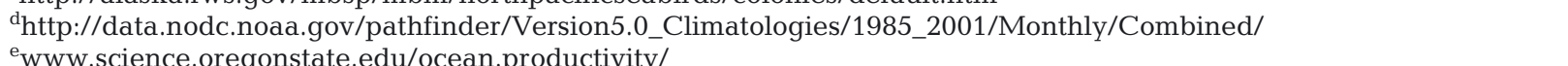 } \\
\hline \multicolumn{5}{|c|}{ f www.afsc.noaa.gov/fma/spatial_data.htm } \\
\hline
\end{tabular}

To identify Bathymetric features quantitatively, we made use of an algorithm developed for landscape analysis (Wood 1996) to characterize the shape of the log-bathymetry for each grid cell. After choosing an appropriate tolerance, a ridge, for example, was defined as a point that lies on a local convexity that is orthogonal to a line with no convexity/concavity (Wood 1996, GRASS Development Team 2009). Bathymetric feature was the only categorical variable in the set; the categories being pits, peaks, planes, ridges, saddles, and channels. We used log-bathymetry in the calculation of Bathymetry to, again, to emphasize shallow water features over those in deep water.

For Sea Surface temperature, we used monthly means (climatologies) across all years to build the models, and the mean across all months included in the dataset to make the predictions for the time series. Missing pixels near the shorelines of perpetually fog-shrouded islands and along the 180th meridian were interpolated from the adjacent pixels using a spline smoother.

Information on Fish catch was made available by the NMFS Alaska Fisheries Science Center observer program (AFSC Observer Program) at a coarse spatial resolution to protect confidentiality (Table 2). We aggregated the catches of all species of fin- fish from all available years over a $10 \mathrm{~km} \times 10 \mathrm{~km}$ vector-grid.

We used long-term means (climatologies) for the dynamic variables Sea surface Temperature, Primary productivity, Fish catch, and colony size (Colony effect) for 2 reasons: (1) Concurrent data was data not available for many years, especially for the 1970s and 1980s. (2) Our main objective was to use this model to look for temporal patterns in the observed:predicted ratios. Adding predictive variables that vary in time would improve the ability to estimate the functional response of fulmar density. However, the ability to detect trends in these ratios would be compromised, as some of that variability would already be explained by the long-term variability of the predictive variable. We were aware of the considerable interannual variation in some of these variables. However, our study area spanned such a large geographic space that we expected interannual variation to be small compared to spatial variation. While the model did not contain an annual component, the observed:predicted ratios of the dependent variable (Fulmar density) could still be analyzed on an annual basis. Because colony attendance varies considerably over the breeding season (Hatch 1989), we added the Day-of-year as a variable to the model. 


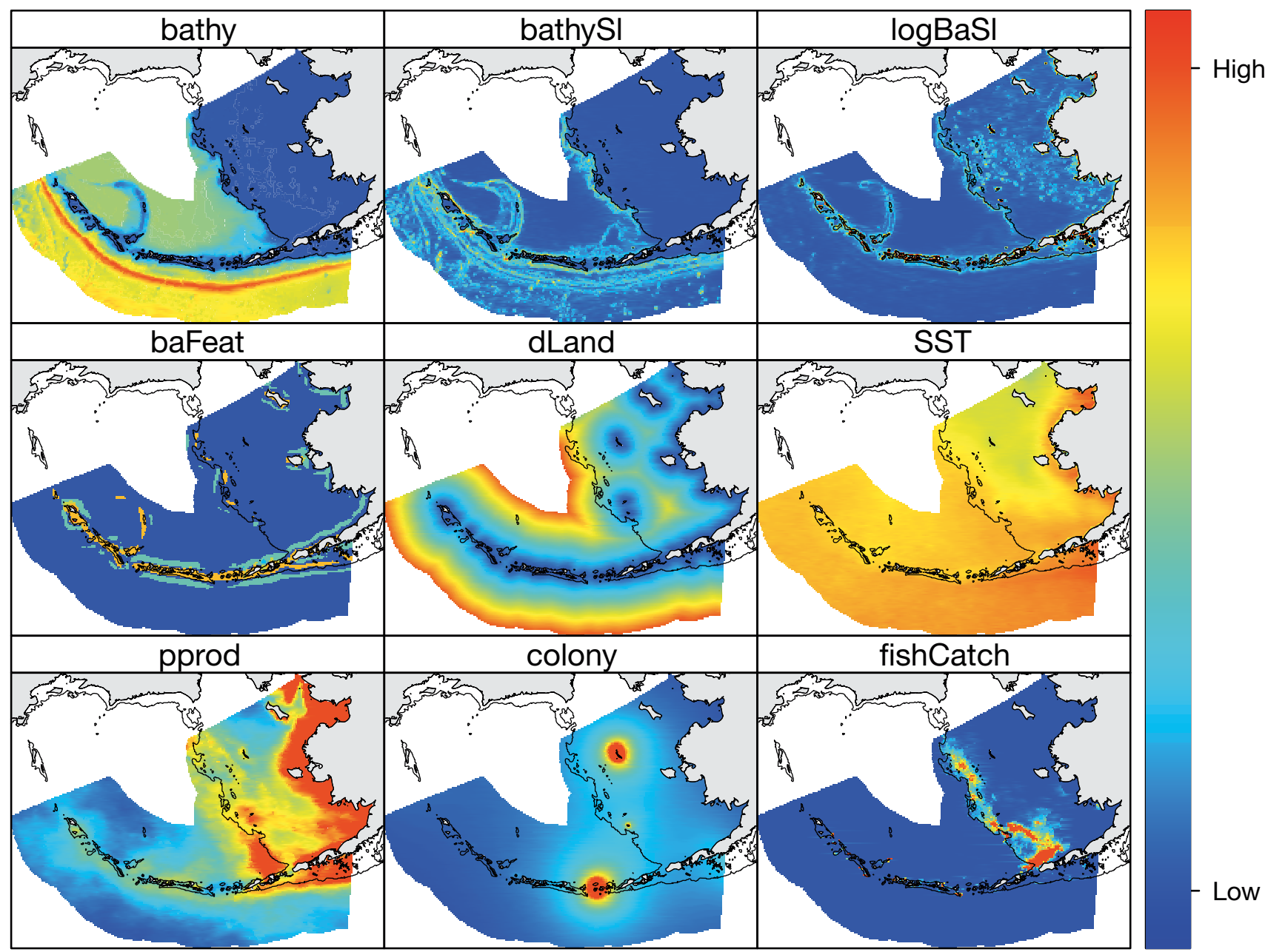

Fig. 3. Physical layers and fisheries catches used to predict northern fulmar Fulmarus glacialis densities. To show the spatial patterns better, we capped the upper 10th percentile of primary productivity, and the upper $1 \%$ of log bathymetry slope, colony effect, total fish catch, and longline catch (only for this figure, not the analysis). 'Bathymetric features' is the only nominal variable. Also shown is the $400 \mathrm{~m}$ isobath marking the continental slope. See Table 2 for abbreviations, variable explanations and sources

\section{Abundance model}

To model the counts of fulmars per transect, we used an ensemble approach — using the mean of 3 predictive models weighted by the inverse root mean squared error from 10-fold cross-validation: generalized additive model (GAM; Wood 2000, Clarke et al. 2003, Wood 2011), multivariate adaptive regression splines (MARS; Friedman 1991, Austin 2007, Hastie et al. 2009), and random forest (Cutler et al. 2007). Ensemble approaches are often superior to a single model (e.g. Burnham \& Anderson 2002, Araújo \& New 2007, Oppel et al. 2012).

Generalized cross-validation allows selection of the smoothing parameters in a GAM to be tuned as if checking it against an independent dataset, thereby avoiding overfitting. MARS is a non-parametric extension of generalized linear models, automatically allowing for non-linearities and interactions between variables. The implementation used here ('earth') allows for hinges, joining 2 straight lines, rather than smooth splines. Variables and hinges are selected through a step-wise process.

Random forest is an ensemble method in itself, combining the ideas of 'bagging' and random selection of features. From a bootstrap sample, a large number of regression trees are fitted (here 500) using randomly chosen variables on each node. Trees are fully grown (rather than pruned), and the results of all trees are averaged for the final prediction. While providing highly accurate predictions, random forest models tend to be difficult to interpret. Used here for 
the predictive regression of abundance, random forest has been shown to be a superior method for presence/absence and diversity distribution models (Marmion et al. 2009, Knudby et al. 2010), but has seen only limited use in abundance models so far.

All variables listed in Table 2 were allowed to enter the respective models. In the case of the GAM, we allowed Bathymetry, Sea surface temperature, and Day-of-year (Day) to be smooth functions. The GAM model was specified as:

$$
\begin{aligned}
& \log \left(N_{\mathrm{s}}+\frac{N_{\mathrm{f}}}{\lambda_{\mathrm{m}}}\right)=\beta_{1} \mathrm{~s}_{1} \mathrm{j} \text { Day }+\beta_{2} \mathrm{~s}_{2} \text { bathy }+\beta_{3} \text { bathyS } 1+ \\
& \left.\beta_{5} \text { dLand }+\beta_{6} \log \text { (colony }\right)+\beta_{7} \text { pprod }+ \\
& \beta_{8} \text { fishCatch }+\beta_{9 \mathrm{~s} 3} \mathrm{SST}+\beta_{10} \text { baFeat }_{\text {planar }}+ \\
& \beta_{11} \text { baFeat }_{\text {slope }}+\beta_{12} \text { baFeat }_{\text {ridge }}+ \\
& \beta_{14} \text { baFeat }_{\text {channel }}+\beta_{14} \text { baFeat }_{\text {mount }}+ \\
& \beta_{16 s 4 x}+\beta_{1756 y}+\beta_{18 s 6 x}: y+\log (\text { Area })+\varepsilon
\end{aligned}
$$

where $N_{\mathrm{s}}$ is the number of swimming, and $N_{\mathrm{f}}$ the number of flying fulmars counted during a transect segment. The flux correction factor $\lambda_{\mathrm{m}}$ was used to allow comparison between the 2 methods (m) used for flying birds; $\lambda_{\mathrm{m}}=1$ when the snap-shot method was used. Applying the correction factor $\lambda_{m}$ to the area offset instead of the count numbers was not possible because swimming and flying birds are counted simultaneously, but the correction only needs to be applied to the flying birds. $\beta_{1-18}$ are the individual parameters fitted by the model, and $s_{1-6}$ are smooth spline functions. The degree of smoothing was determined through generalized cross-validation (Wood 2000), and variables were selected through shrinkage.

We considered 2 error distributions: the negative binomial and the quasi-Poisson, both of which allow for overdispersion. Ver Hoef \& Boveng (2007) showed that the quasi-Poisson distribution gave greater weight to large aggregations and was therefore more appropriate when a high proportion of the total population was found in a few large aggregations. In our sample, we found that over $50 \%$ of all birds were in flocks larger than 60 birds, while the mean flock size was only 14 birds. We therefore built our models using the quasi-Poisson distribution. We used a log-link function and log (bin-area) as an offset. The offset allowed us to model discrete counts per bin, while taking different bin sizes into account, thereby effectively modeling density rather than counts. The MARS and random forest models were set up equivalently, but without the terms for geographic location.

To estimate variable importance, we made predictions for each variable over its observed range, while holding the remaining variables constant at their respective means. We computed the standard deviation of the predicted counts and scaled them relative to the variable with the greatest variance.

\section{Time series}

To test whether fulmar abundance in the Bering Sea has responded to observed changes in climate and changes in fishing practices, we derived a time series of the fulmar at-sea abundance (NOFU). Using the ensemble model, we predicted counts over a $10 \mathrm{~km}$ grid of the entire study area. For each grid cell we used the mean of the continuous, and the mode of categorical variables. Day-of-year was set to 30 July, which usually falls in the incubation period for northern colonies and around hatch time for southern colonies. We chose this date because colony attendance during these phases is comparatively constant (Hatch 1989).

From the sum, $P$, of this predicted at-sea abundance, we derived annual abundance estimates by applying the mean ratio of fitted $F$ to observed values $O$ to $P$ for every year a from Year 1 to Year $N_{a}$ :

$$
\mathrm{NOFU}_{a}=P \frac{\sum_{i=1}^{i=N_{a}} \frac{F_{i, a}}{O_{i, a}}}{N_{a}} \frac{\sum O}{\sum F}
$$

We fitted a GAM to the annual estimates, to allow for variations in the population trajectory over this rather long period of time. We set the smoothing parameter through generalized cross-validation. We calculated $95 \%$ confidence intervals for the annual population estimates by bootstrapping the ratio $\frac{F_{i}}{O_{i}}$ using 999 replicates. The caveat to these confidence intervals is that not only the number of $3 \mathrm{~km}$ or 10 min bins, but also the spatial coverage varies between years. While there was good coverage in the early and the late parts of the study period, for some years only a few localized surveys are available. The confidence limits are a valid estimate of the uncertainty within the sampled area, but can only be indicative for the entire study area when sampling is geographically limited. To address this uncertainly for individual years (which is also a function of the varying sample size over years), we weighted the GAM by the inverse of the range of the confidence interval. For comparison, we applied these steps not only to the ensemble model, but to the MARS, GAM, and random forest habitat models as well. 


\section{Change in latitudinal distribution}

To test for shifts in the latitudinal distribution of fulmars while accounting for the heterogeneity of the dataset, we averaged densities over a $10 \mathrm{~km} \times 10 \mathrm{~km}$ grid, assuming that data within any one grid-cell were comparable through time (Fig. 2). Missing data, i.e. grid cells that were not surveyed in any 1 yr, were interpolated through time (but not space). Missing values in the earliest and latest years were replaced with the closest neighbor in time. The now complete matrix could be analyzed for changes in latitude (center of gravity) by using mean density per grid cell as weights in a regression of latitude (of grid cell) over time. We used a cross-validated GAM for fulmars and for comparison a weighted linear regression for the shorter time series of fish catches.

\section{Software tools}

We used R (R Development Core Team 2011) for almost all calculations. GRASS GIS (Neteler \& Mitasova 2008) in conjunction with the R packages 'sp' and 'spgrass6' were used for all GIS operations. Models were fit using $\mathrm{R}$ with the packages 'Ime4' (GLMM), 'mgcv' (GAM), 'earth' (MARS), and 'randomForest' (Liaw \& Wiener 2002).

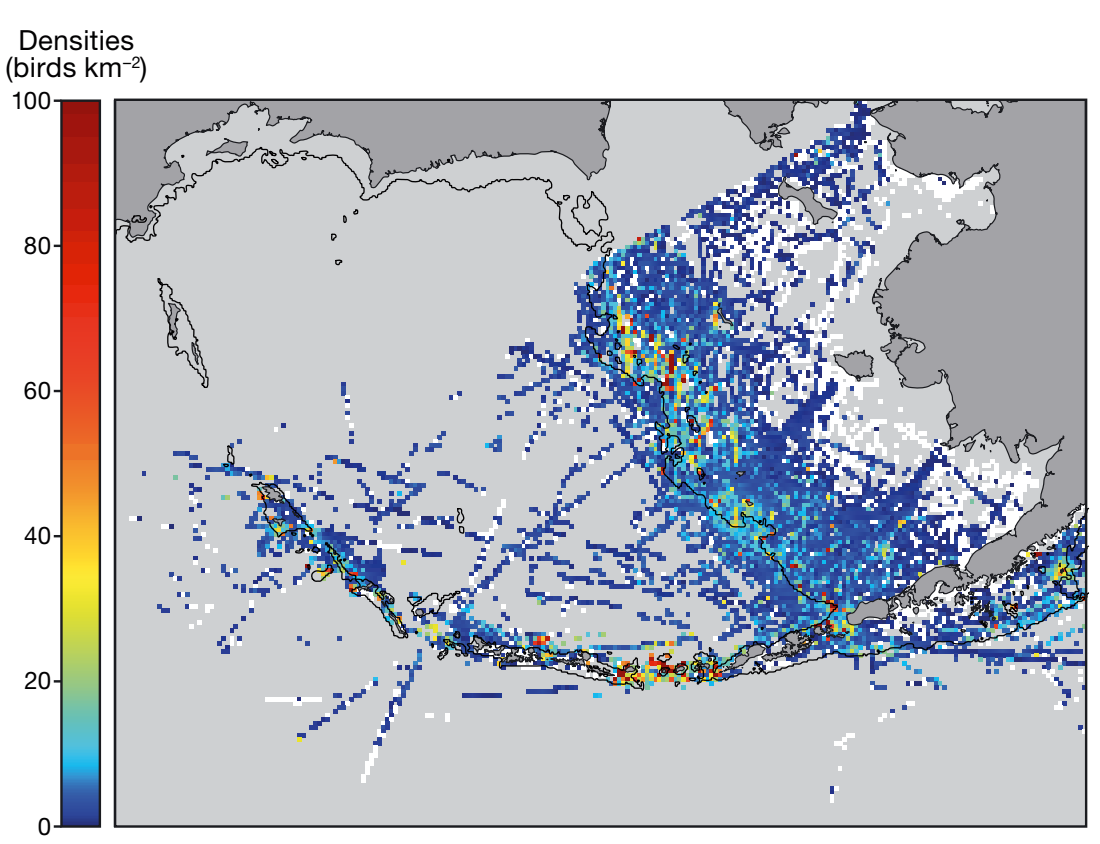

Fig. 4. Fulmarus glacialis. Observed average densities (birds $\mathrm{km}^{-2}$ ) of northern fulmars between May and early September in the Bering Sea between 1975 and 2009 within a $10 \mathrm{~km} \times 10 \mathrm{~km}$ grid. Gray pixels were not surveyed; white pixels were surveyed but no birds were found. Densities above 100 birds km-2 were truncated

\section{RESULTS}

\section{Distribution}

We found fulmars throughout most of our study area. A plot of the observed densities, averaged over the entire time period, revealed high concentrations along the outer continental shelf and along the Aleutian Archipelago (Fig. 4). Two off-shore hotspots stand out: one to the south-west of Saint Matthew Island and one between the Pribilof Islands and Unimak Pass (see Fig. 1 for locations). Areas where fulmars were found at zero or nearzero densities included the shallow waters of the inner domain of the Bering Sea, and areas far offshore over the deep waters of the Bering Sea Basin and the North Pacific.

\section{Model selection and variable importance}

Fulmar density showed the strongest relationship with Bathymetric features based on a Poisson regression and a univariate MARS model (Table 3). Fulmar densities were higher over underwater ridges than over other features like flats or channels. Spearman rank correlations with fulmar density were strongest with Colony effect, Bathymetry and Fish Catch, but could not be calculated for Bathymetric Features. Slope of bathymetry and Sea surface temperature had similarly high values of $\rho$, whereas $\rho$ values of the slope of Logbathymetry, Primary productivity and Distance to land were close to zero. The best univariate MARS models after Colony effect were based on Bathymetric features (ridges), Fish catch, and Bathymetry. Primary productivity and Distance to land ranked low in all of the univariate model sets.

To predict the spatial distribution of fulmar abundances, we built an ensemble model, based on GAM, MARS, and random forest models, using all predictor variables simultaneously. Model weights for the GAM, MARS and random forest models were practically equal at $0.332,0.335$ and 0.333 , respectively. To visualize the structure of the ensemble model, we plotted the effect of each variable in the model, holding all other vari- 
Table 3. Fulmarus glacialis. Univariate models explaining northern fulmar distribution, contrasting natural factors and fisheries. We show Spearman's $\rho$ from rank correlation with fulmar density, the difference in deviance of a Poisson regression on fulmar counts (with a survey-area offset) and the best Poisson model (low values indicating a better fitting model), and the $\mathrm{r}^{2}$ of the respective multivariate adaptive regression splines (MARS) model. Note that here only the MARS model allows for a non-monotonous relationship. The table is sorted by the mean rank $\mathrm{k}$ of the 3 measures

\begin{tabular}{|lcccc|}
\hline Variable & $\rho$ & $\Delta$ deviance & MARS $\mathrm{r}^{2}$ & $\overline{\mathrm{k}}$ \\
\hline Bathymetric features & & 0 & 0.002 & 1.5 \\
Colony effect & 0.24 & 10383 & 0.00889 & 1.7 \\
Bathymetry & 0.27 & 43109 & 0.00126 & 3 \\
Fish catch & 0.23 & 46977 & 0.00144 & 4 \\
Sea surface temperature & 0.17 & 46606 & 0 & 5.5 \\
Primary productivity & -0.04 & 42873 & 0 & 5.5 \\
Distance to land & 0.01 & 59536 & 0.00118 & 6.7 \\
Slope of bathymetry & 0.07 & 67860 & 0 & 7.2 \\
Slope of log-bathymetry & 0.02 & 64049 & 0 & 7.5 \\
\hline
\end{tabular}

series showed a decline from an average at-sea density of $6.75 \pm 0.53$ birds $\mathrm{km}^{-2}$ in 1975 to $5.10 \pm 0.40$ birds $\mathrm{km}^{-2}$ by 2009 at a constant rate of $-0.83 \pm 0.39 \%$ (SE) per year (Fig. 7 ). This translates to a total decline of $24.7 \%$ over the time period from 1975 to 2009. Note that all models showed a decline, but estimates of at-sea abundance as well as shape of the trend varied considerably among model results. Generalized cross-validation supported several nodes in the abundance trends of all models other than the ensemble model - the trend of which was reduced to a straight line. These patterns were similar when using the extreme values ( 1 or 5 ) for the correction factor of flying birds $\lambda$. Using these extreme

ables constant (Fig. 5). Colony effect was the single most important predictor. Other important predictors included Sea surface temperature, Fish catch and Geographic location ( $x$ and $y$ ). The effect of Fish catch showed a threshold above which additional fishing activity would lead to only minor increases in fulmar densities. The function of Day-of-year on fulmar densities was somewhat bell-shaped, peaking in early July.

The predicted at-sea distribution showed high concentrations of fulmars on the Bering Sea continental shelf close to the shelf break, and in the Aleutian Archipelago (Fig. 6). Localized hotspots were found around the largest colony on Chagulak Island and in adjacent passes, in the 'elbow' north of Unimak Pass, and at an off-shore area on the shelf adjacent to Zhemchug Canyon. Low densities were predicted for shallow coastal waters and deep off-shore waters. The predicted hotspots were also found in the aggregated observed data in the form of spatially smaller but denser aggregations (Fig. 4). The different models agreed on the hotspot around Chagulak, but differed in the predicted extent and size of some of the other areas of high density. We based the following time series analysis on the predictive ensemble model.

\section{Time series}

Using the annual deviations from the locallypredicted at-sea densities, we derived a time series of fulmar at-sea abundance. A GAM of the time values of $\lambda$, the estimated annual rates of decline for the ensemble model were $1.4 \pm 0.39 \%$ for $\lambda=1$, and $0.35 \pm 0.45 \%$ for $\lambda=5$, respectively.

Given that the temporal GAM from the spatial ensemble model failed to reveal changes in the slope of the abundance trend over the years, we refrained from a formal analysis relating this trend to climate or biological variables. While any time series with a strong directional trend will show a high correlation with the trend in fulmar abundance, the inherent autocorrelation precludes a convincing quantitative argument for causal relationships.

\section{Changes in distribution}

Using a temporal GAM of latitude, weighted by interpolated densities within $10 \mathrm{~km} \times 10 \mathrm{~km}$ grid cells, we looked for changes in distribution over time. We found a northward shift in the center-ofgravity of fulmar distribution in the Bering Sea (excluding the Aleutian Archipelago). A similar, but 3 times faster shift northward was found in the distribution of fishery catches (Fig. 8). While fulmar densities have seen increases in the north, the distributional shift in fishery catch was largely due to reduced catches in the southern Bering Sea, rather than a range-expansion at the northern edge (Fig. 8b). Although the temporal GAM allowed for a flexible model, the level of smoothing chosen by generalized cross-validation resulted in a straight line. 

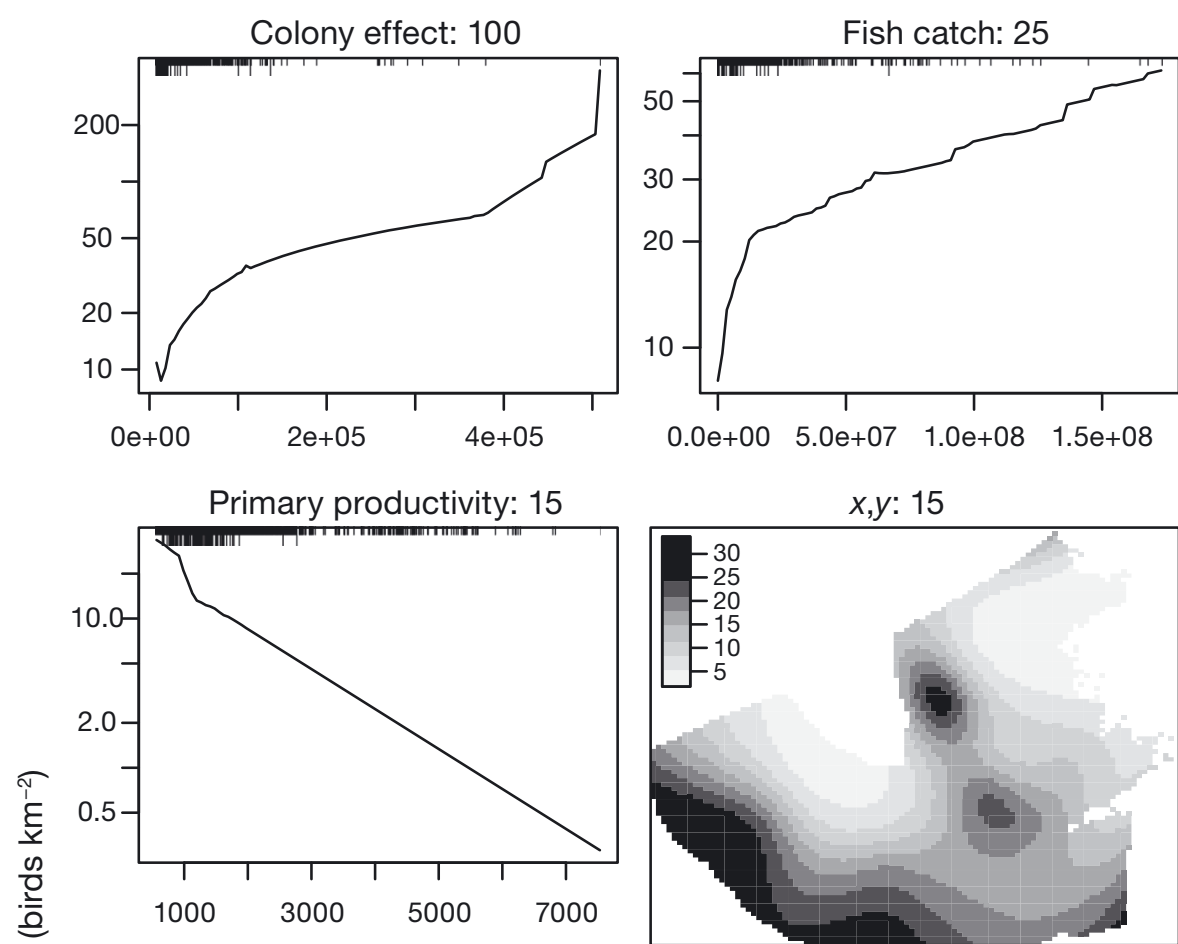

$\frac{7}{0}$
$\frac{2}{0}$
$\frac{0}{0}$
$\frac{0}{0}$
$\frac{1}{0}$
$\frac{0}{0}$
$\frac{1}{0}$

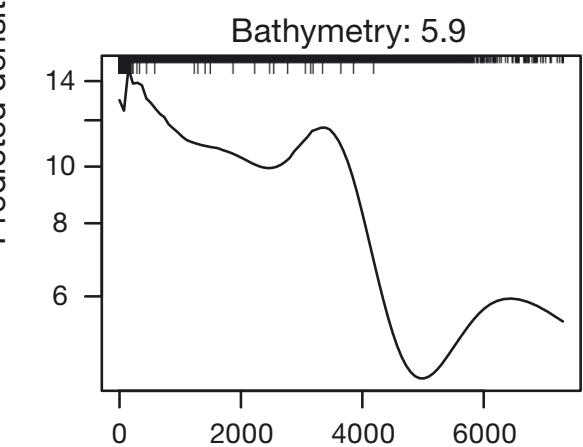

Slope of bathymetry: 3.3

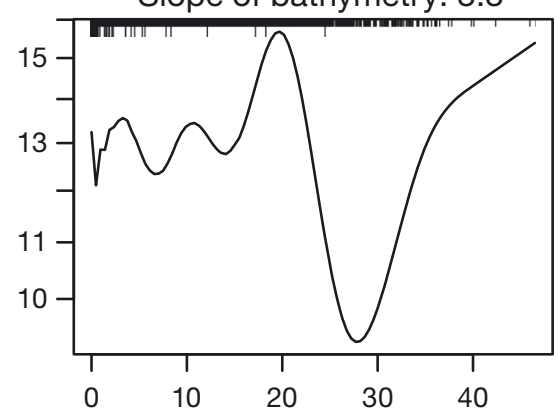

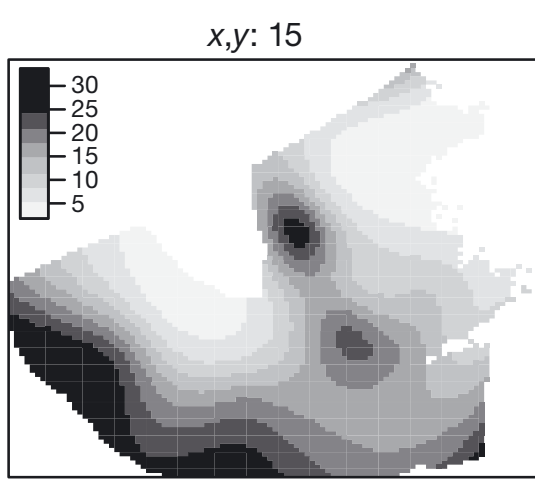

Fish catch: 25

Date: 5.7

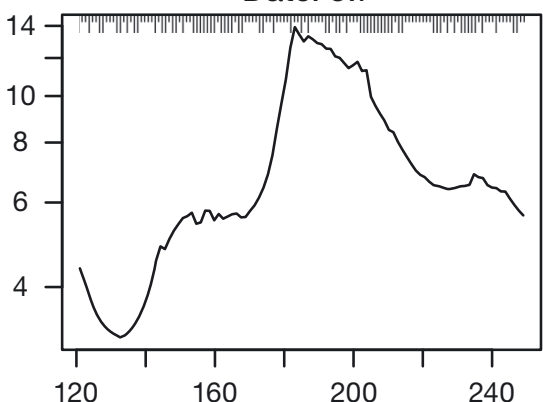

Slope of log-bathymetry: 3

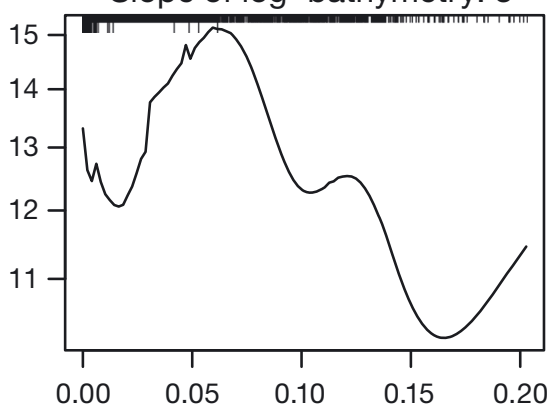

Sea surface temperature: 21

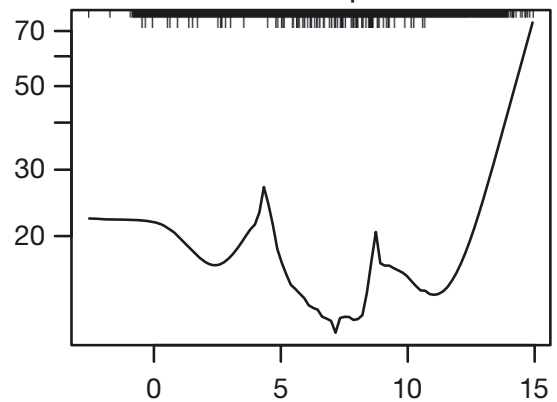

Bathymetric features: 6.1

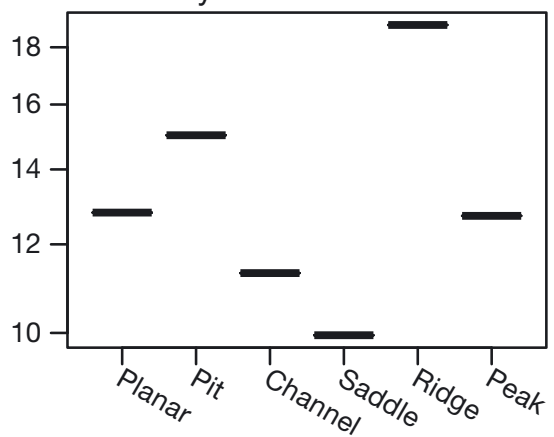

Distance to land: 3.5

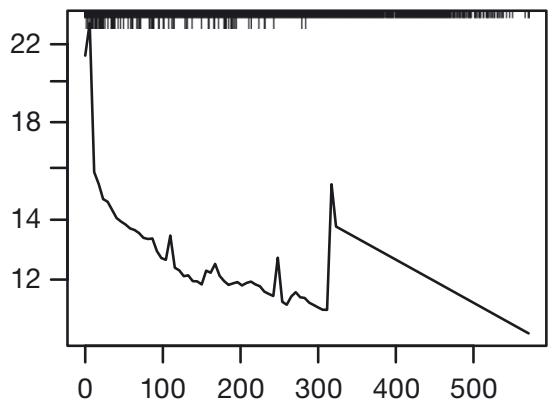

Fig. 5. Effects of the ensemble model of fulmar distribution in the Bering Sea. The $y$-axis shows the predicted fulmar densities if all but the variable plotted on the $x$-axis were held constant. The numbers in the titles refer to the effect size, relative to the most important variable, colony effect. The tick-marks indicate the distribution of the predictive variable. Note that the $y$-axis is on a log-scale
DISCUSSION

Modeling of at-sea data revealed high densities of fulmars along the edge of the continental shelf, around the major colony of Chagulak Island, and near Zhemchug Canyon. Our model indicates that fulmars have declined by $0.83 \%$ per annum, or about
$24 \%$ from 1975 to 2009. Additionally, the center of gravity of fulmar at-sea distribution has shifted northward, coinciding with a northward shift in the distribution of fish catches.

While a large proportion of the literature is concerned with modeling distribution of occurrence from presence/absence or presence-only data, com- 
Densities

(birds $\mathrm{km}^{-2}$ )

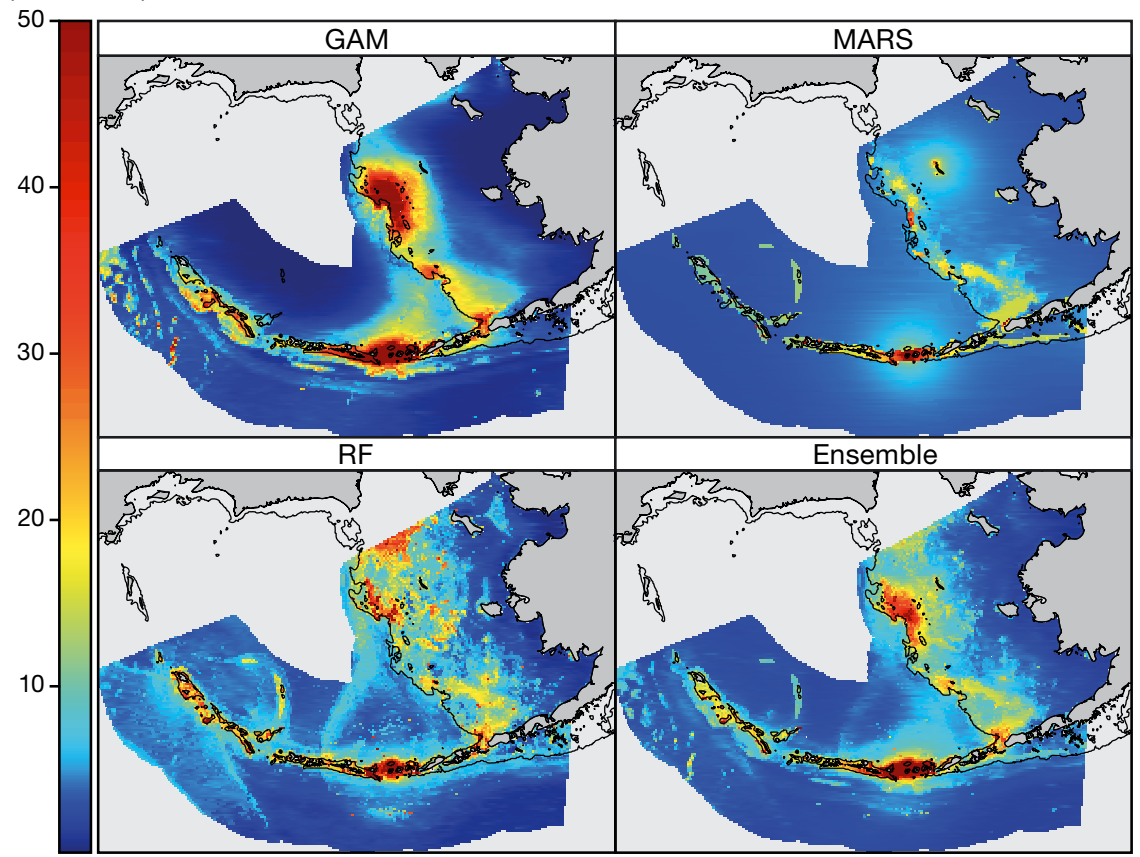

Fig. 6. Fulmarus glacialis. Distribution of northern fulmar at-sea densities in the Bering Sea and Aleutian Archipelago as predicted by 3 different predictive models and an ensemble of those 3 for 30 July, based on data from the breeding season (May-early September) and the years 1975-2009. Color scale is capped at a density of 50 birds $\mathrm{km}^{-2}$. Note the general agreement in large-scale patterns, but differences in size and location of high-density areas on the Bering Sea shelf, the north of which is only sparsely surveyed (Fig. 5). GAM: generalized additive model; MARS: multivariate adaptive regression splines; RF: random forest model

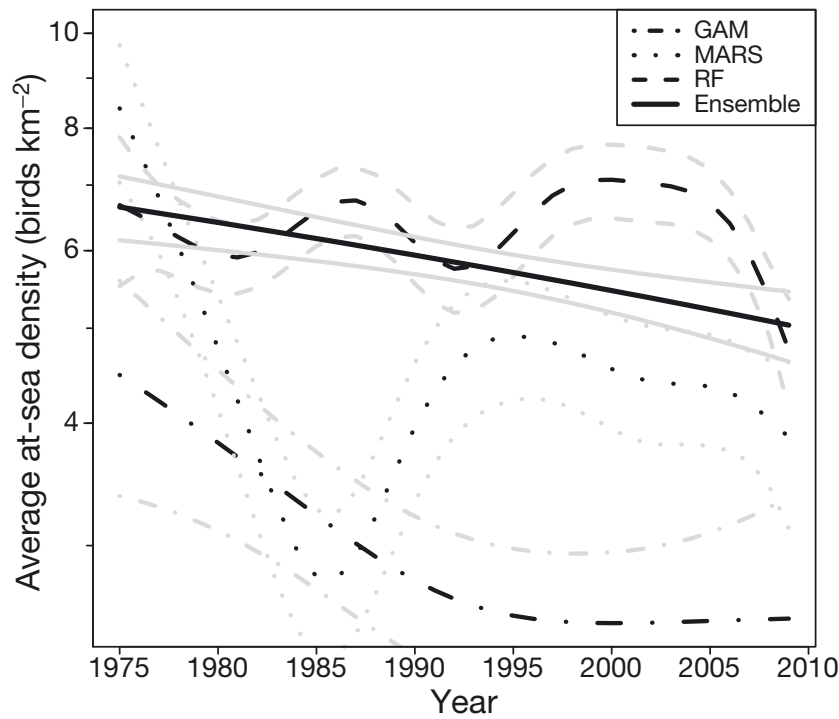

Fig. 7. Fulmarus glacialis. Estimated trends of northern fulmar Fdensities in the Bering Sea as indicated by at-sea surveys, based on ratios of observations to predictions of one of 4 different spatial models, including an ensemble model. Annual estimates were smoothed using cross-validated temporal GAMs, weighted by the inverse range of the confidence intervals of the annual estimates. Shown are the temporal GAMs with their standard errors in gray. Note that the $y$-axis is scaled logarithmically paratively little attention has been paid to modeling the spatial distribution of abundance. Ensemble models have performed well in a previous study (Oppel et al. 2012), but more research in this field is clearly needed. It may appear peculiar that the ensemble model (an average of the 3 other distribution models) resulted in a lower population estimate than the GAM, MARS or random forest models (Fig. 7). We interpret this as a result of slight differences in the predicted location of hotspots, especially on the Bering Sea shelf. Our results show that model selection can affect the results and their interpretation considerably (see Figs. 6 \& 7).

Colony effect was the most important variable predicting fulmar distribution and abundance during the breeding season. Colony location is a prominent feature in almost any telemetry study, but is rarely used in vessel-based at-sea studies (but see Kinder et al. 1983, Decker \& Hunt 1996, Huettmann \& Diamond 2001, McSorley et al. 2006). For largescale studies and species with overlapping foraging areas between adjacent colonies, a multi-colony approach, as shown here, is necessary. Many of the extant fulmar colonies in the Bering Sea are long-established, driven by factors predating the advent of modern fisheries in the region. Those hotspots of fulmar densities that overlap with commercial fishing activities are in near-shelf-edge areas that appear to be suitable fulmar habitat elsewhere in the North Pacific. What makes these zones particularly attractive is the combination of natural and anthropogenic food.

Both the univariate exploration, as well as the ensemble model, indicated that Fish catch was an important variable for explaining the distribution of fulmars. We suggest that the explanatory importance of Fish catch reflects the importance of fishing activity as the underlying reason for the northward shift in the pelagic distribution of fulmars in the Bering Sea. We are unaware of any data suggesting a northward shift in the location of fulmar colonies, or of the numbers of individuals attending extant fulmar colonies, although if the northward shift of the foraging range is long-lasting, we would expect a gradual northward shift of the breeding population. 


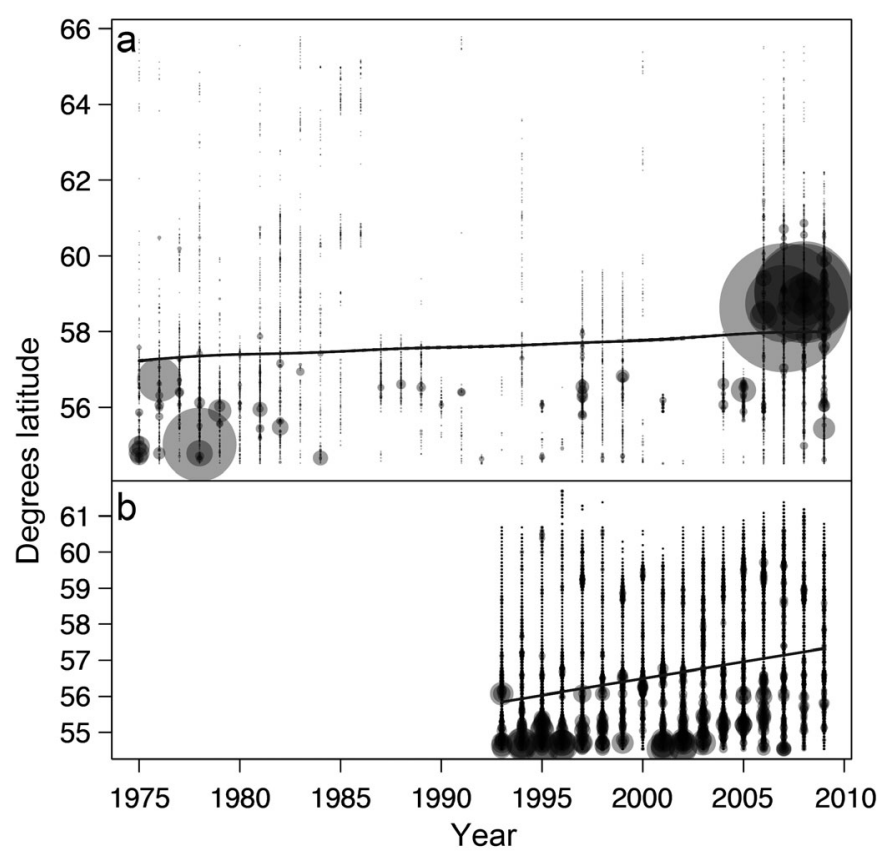

Fig. 8. Change in the latitudinal distribution of (a) northern fulmars and (b) fisheries catches in the Bering Sea (excluding Aleutian Islands). Both datasets were first aggregated over a $10 \mathrm{~km} \times 10 \mathrm{~km}$ grid, so each data point represents one grid cell. Size of the circles is proportional to (a) the size of the average bird density (prior to interpolation) and (b) fish landings per grid cell. Regression slopes translate to a northwards shift in distribution at a rate of $2.43 \mathrm{~km} \mathrm{yr}^{-1} \pm$ $0.06 \mathrm{~km} \mathrm{yr}^{-1}$ in fulmars and $10.30 \mathrm{~km} \mathrm{yr}^{-1} \pm 0.06 \mathrm{~km} \mathrm{yr}^{-1}$ in fish catches. Note that the shift in the center of gravity of the fisheries is due to a reduction in fish catches in the south rather than an expansion at the northern extreme. Confidence intervals are too narrow to be clearly visible. A crossvalidated weighted temporal GAM of the fulmar distribution did not differ from the straight line, suggesting that the straight line is the best predictor supported by the data

Bathymetric features, principally bathymetric ridges, ranked highly when taken by themselves, but their importance was much reduced in the ensemble model. Bathymetric ridges were particularly prominent along the continental shelf break, emphasizing the shelf-edge as an important habitat feature of fulmars. While much of the Bering Sea fishing activity also occurs near the shelf edge (Fig. 3), there are numerous exceptions where shelf-edge habitat is not fished or where large fisheries occur away from shelf edge habitat. We found only weak correlations between fulmar density and Sea surface temperature, and even weaker correlations with Primary productivity. Primary productivity was more important in the ensemble model. We have no ready explanation as to why the relationship between Primary productivity and Fulmar density is negative, however.
Using the ensemble model, we can produce an estimate of fulmar at-sea abundance independent of colony-based counts by multiplying the average predicted density (from Fig. 7 by the size of the study area $\left(2.33\right.$ million $\mathrm{km}^{2}$ ). This would yield an at-sea population of 15.7 million in 1975 that declined to 11.9 million birds by 2009. This estimate does not include birds attending an egg or chick on land. The North Pacific seabird colony database covers the entire range of fulmars in the Pacific and lists a total of 2.2 million individual breeding fulmars (not pairs; Migratory Bird Management 2010). Considering only birds breeding within the study area would leave us with an estimated 984000 breeding birds. Adjusting for $30 \%$ non-breeders (Hatch 1987), we get 3.1 million and 1.4 million for the North Pacific and the study area, respectively.

We suggest that this discrepancy between the atsea-based estimate and the colony-based estimate of about an order of magnitude has 2 causes: (1) vessel attraction leads to an overestimation of actual fulmar at-sea densities. (2) The largest fulmar colonies host considerably more birds than the colony catalog suggests. Hyrenbach (2001) reported that ship-based surveys overestimate albatross densities off California by a factor of 4 . While observers in our study were instructed not to count obviously ship-following birds, there is no known antidote against ship-attraction.

Additional at-sea surveys (especially close to the major colonies) would help to reduce the uncertainties of model predictions. There is a need for better estimates of the effects of vessel attraction and ship following on standard survey methods and how these vary across species and group sizes.

If detectability were a source of a major bias in this study, we would have expected an at-sea population estimate lower than the comparable estimate from terrestrial data. Because our ship-based population estimates were higher than those based on colony counts, it is reasonable to assume that detectability was at most a minor source of bias to the at-sea population estimate.

There is no established method for estimating the enormous numbers of fulmars breeding in the largest colonies. The slopes of Chagulak Island are near-vertical and usually covered in fog (Fig. 9). The counts of this colony were incomplete, at best, and given the clouds of fulmars circling this island, it is easy to imagine that the actual numbers are substantially larger than the estimate in the current version of the colony catalog.

It is likely that our finding of a decline in the number of fulmars at sea is correct. We have corrected for 
the change in methods for the recording of flying birds, and biases such as ship attraction or detectability are unlikely to have changed over the course of the study period. Using a generation length of $18.8 \mathrm{yr}$ (Jones et al. 2008), the decline extrapolated from our analysis for Pacific fulmars over 3 generations is (1 $0.0083)^{3 \times 18.3} \approx 1-0.38$. A $38 \%$ decline over 3 generations meets the IUCN criteria A2 for 'vulnerable' (IUCN 2001).

Fisheries can be both a source of mortality and a source of food for seabirds such as fulmars. Population declines of some seabird species, especially albatrosses, have been linked to high mortality rates of adult birds as bycatch, especially in longline fisheries (Tuck et al. 2001, Arnold et al. 2006, Delord et al. 2008). Fulmars are the most common seabird species accidentally killed in Alaskan fisheries (Dietrich \& Fitzgerald 2010). Our estimate of the at-sea abundance of fulmars confirms that the total number of birds in the population dwarf the number of birds accidentally killed in fisheries, even during the height of fisheries bycatch of fulmars in the late 1990s, when over 16000 fulmars were killed in a single year (Melvin et al. 2004). Bycatch mitigation measures (Melvin \& Parrish 2001, Melvin et al. 2001), which have been implemented since the late 1990s and are now mandatory, have been highly successful and have dramatically reduced the number of birds killed (Moore et al. 2009).

Conversely, fishing vessels bring otherwise inaccessible fish to the surface, which can be taken by fulmars when the catch is being hauled up or when

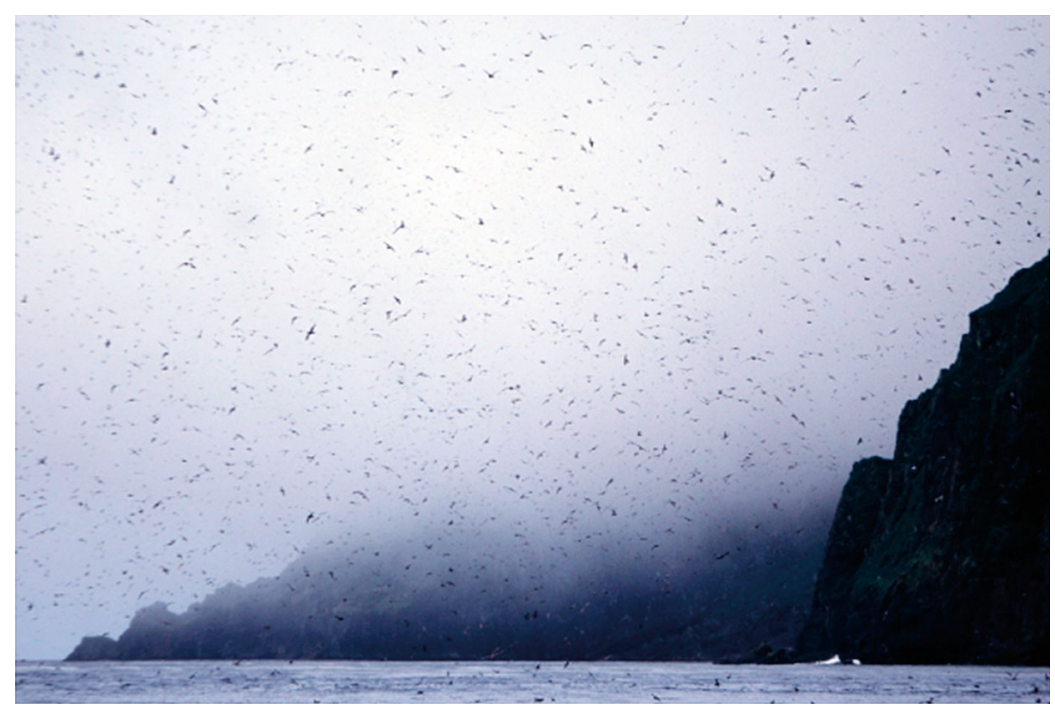

Fig. 9. Small section of the world's largest fulmar colony at Chagulak Island, Alaska. No quantitative census has ever been conducted on this island, nor has a method been proposed how this could be done. Photo: M. Renner bycatch and offal are being discharged. While no fulmar population is known to rely exclusively on discards or offal, anthropogenic food plays an important role at least in some populations (Phillips et al. 1999). As expected under the hypothesis that discharge should have a positive effect on fulmar populations, a decline in the tonnage of fish caught (Bailey 2000) coincided with the decline of fulmars documented here.

Total fishery catch provides a consistent metric over the decades of food available to scavenging seabirds as long as fishing and especially fish processing methods do not change over time. However, over the 4 decades of this study, political and economic factors have influenced rates, types, and locations of discards and offal discharged into the Bering Sea. Examples include the reorganization of the fishery from largely international to domestic by the Magnuson-Stevenson Act, the rising value of fish as a commodity, and the adoption of ecosystem-based fisheries management.

Estimates by NMFS of fisheries discharge (discards and offal combined) for the largest Bering Sea fishery, the midwater-trawl pollock fishery, are available from 1996 to 2005, during which time discharge declined by about a quarter (A. E. Edwards unpubl. data). The midwater-trawl fishery is highly selective and has a much lower discard rate of entirely-unwanted fish (currently $<1 \%$ ) compared to the pelagic trawl or longline fisheries $(>10 \%)$. However, the larger catches and considerable atsea processing facilities of the midwater trawl fishery result in higher total discharge rates of macerated offal, which forms the majority of the fisheries-discharge made available to fulmars in the Bering Sea.

A series of changes to processing standards in the 1990s enabled retention of a greater proportion of each marketable fish, thereby reducing the offal discharge rate, and also increased the proportion of the total catch that was processed on shore. Consequently, the proportion of the catch made available to scavenging fulmars relative to the total fisheries catch of the Bering Sea declined during the late 1990s (A. E. Edwards unpubl. data). However, given that the temporal GAM of the ensemble model resulted in a straight line, we have no strong evidence linking 
changes in fishing or processing standards with the change in fulmar populations.

A major climatic regime shift in the North Pacific in the late 1970 s is believed to have triggered largescale changes in the organization of the ecosystem in the Gulf of Alaska (Anderson \& Piatt 1999). Considerable changes in the ecosystem of the Bering Sea have been observed on a similar time scale (Trites et al. 2007, Mueter \& Litzow 2008). The drop in fish catches with an associated drop in discharge and supplementary food provides an immediate mechanism for changes in fulmar populations. However, we cannot distinguish between this and the possibility that fisheries and fulmars were merely affected by the same underlying changes in the ecosystem.

\section{CONCLUSIONS}

By comparing a model of a seabird species' at-sea abundance distribution to observed data, we developed a novel approach for population monitoring. Our analyses suggest that there has been a substantial decline in the numbers of fulmars present at sea in the eastern Bering Sea and Aleutian Islands since the 1970s. Not surprisingly, fisheries play an important, but not the most important, role in shaping the pelagic distribution and abundance of fulmars in the Bering Sea and Aleutian Archipelago. We found that a northward shift in the pelagic distribution of fulmars coincided with changes in the location of fisheries catches. However, we could not determine the relative importance of fisheries or climate-related changes in the food web as factors in the changes in the size of the fulmar population based on at-sea observations.

Acknowledgements. We acknowledge the help of M. Arimitsu, R. Bivand, C. Camphuysen, D. Dragoo, G. Drew, B. Drummond, S. Fitzgerald, S. Hatch, J. Jahncke, E. Labunski, N. Nur, A. Punt, and H. Renner during the course of this project. We appreciate the efforts, suggestions, and criticisms of 5 anonymous reviewers, which helped to improve this manuscript from its original version. We thank all the observers who spent long hours in often inclement conditions to gather the data reported here. The research was supported, in part, by the North Pacific Research Board (projects \#609 and \#637), the National Science Foundation (grant ARC-0908262), the National Research Council postdoctoral fellowship program, the US Geological Survey, and the Alaska Maritime National Wildlife Refuge in form of logistical and in-kind support. This is NPRB contribution \#442, and BEST-BSIERP Bering Sea Project publication \#99. Use of trade names is for descriptive purposes only and does not imply endorsement by the US government.

\section{LITERATURE CITED}

Anderson PJ, Piatt JF (1999) Community reorganization in the Gulf of Alaska following ocean climate regime shift. Mar Ecol Prog Ser 189:117-123

Anderson ORJ, Small CJ, Croxall JP, Dunn EK, Sullivan BJ, Yates O, Black A (2011) Global seabird bycatch in longline fisheries. Endang Species Res 14:91-106

Araújo MB, New M (2007) Ensemble forecasting of species distributions. Trends Ecol Evol 22:42-47

Arnold JM, Brault S, Croxall JP (2006) Albatross populations in peril: a population trajectory for black-browed albatrosses at South Georgia. Ecol Appl 16:419-432

Artyukhin YB, Vinnikov A, Terentiev DA (2006) Seabirds and bottom longline fishery in the Kamchatka region. Environmental impacts of fisheries. World Wide Wildlife Fund for Nature (WWF) Tech Rep, Moscow

Ashmole N, Ashmole M (1967) Comparative feeding ecology of sea birds of a tropical oceanic island. Bulletin 24, Peabody Museum of Natural History, New Haven, CT

Austin M (2007) Species distribution models and ecological theory: a critical assessment and some possible new approaches. Ecol Model 200:1-19

Baduini CL, Hyrenbach KD, Coyle KO, Pinchuk A, Mendenhall V, Hunt GL Jr (2001) Mass mortality of short-tailed shearwaters in the south-eastern Bering Sea during summer 1997. Fish Oceanogr 10:117-130

> Bailey KM (2000) Shifting control of recruitment of walleye pollock Theragra chalcogramma after a major climatic and ecosystem change. Mar Ecol Prog Ser 198:215-224

Bartumeus F, Guiggioli L, Louzao M, Bretagnolle V, Oro D, Levin S (2010) Fishery discards impact on seabird movement patterns at regional scales. Curr Biol 20:215-222

Benowitz-Fredericks Z, Shultz MT, Kitaysky AS (2008) Stress hormones suggest opposite trends of food availability for planktivorous and piscivorous seabirds in 2 years. Deep-Sea Res II 55:1868-1876

BirdLife International (2008) Threatened birds of the world 2008. BirdLife International, Cambridge

Burg TM, Lomax J, Almond R, Brooke M de L, Amos W (2003) Unravelling dispersal patterns in an expanding population of a highly mobile seabird, the northern fulmar (Fulmarus glacialis). Proc R Soc Lond B 270:979-984

Burnham KP, Anderson DR (2002). Model selection and inference: a practical information-theoretic approach, 2nd edn. Springer-Verlag, New York, NY

Byrd GV, Merrick RL, Piatt JF, Norcross BL (1997) Seabird, marine mammal, and oceanography coordinated investigations (SMMOCI) near Unimak Pass, Alaska. In: Forage fishes in marine ecosystems. Proceedings of the international symposium on the role of forage fishes in marine ecosystems. University of Alaska Sea Grant College Program, Fairbanks, AK, p 351-364

Byrd GV, Sydeman WJ, Renner HM, Minobe S (2008) Responses of piscivorous seabirds at the Pribilof Islands to ocean climate. Deep-Sea Res II 55:1856-1867

Camphuysen CJ, Garthe S (1997) An evaluation of the distribution of scavenging habits of northern fulmars (Fulmarus glacialis) in the North Sea. ICES J Mar Sci 54: 654-683

> Cherel Y, Ridoux V, Weimerskirch H, Tveraa T, Chastel O (2001) Capelin (Mallotus villosus) as an important food source for northern fulmars (Fulmarus glacialis) breeding at Bjørnøya (Bear Island), Barents Sea. ICES J Mar Sci 58:355-361 
Clarke E, Spear LB, McCracken M, Marques F, Borchers D, Buckland S, Ainley DG (2003) Validating the use of generalized additive models and at-sea surveys to estimate size and temporal trends of seabird populations. J Appl Ecol 40:278-292

Coyle KO, Eisner LB, Mueter FJ, Pinchuk AI and others (2011) Climate change in the southeastern Bering Sea: impacts on pollock stocks and implications for the oscillating control hypothesis. Fish Oceanogr 20:139-156

> Croxall JP, Rothery P, Pickering S, Prince PA (1990) Reproductive performance, recruitment and survival of wandering albatrosses Diomedea exulans at Bird Island, South Georgia. J Anim Ecol 59:775-796

Cury PM, Boyd IL, Bonhommeau, Anker-Nilssen T and others (2011) Global sea response to forage fish depletion one third for the birds. Science 334:1703-1706

> Cutler DR, Edwards TC Jr, Beard KH, Cutler A, Hess KT, Gibson J, Lawler JJ (2007) Random forests for classification in ecology. Ecology 88:2783-2792

> Decker MB, Hunt GL Jr (1996) Foraging by murres (Uria spp.) at tidal fronts surrounding the Pribilof Islands, Alaska, USA. Mar Ecol Prog Ser 139:1-10

> Delord K, Besson D, Barbraud C, Weimerskirch H (2008) Population trends in a community of large procellariiforms of Indian Ocean: potential effects of environment and fisheries interactions. Biol Conserv 141:1840-1856

> Di Lorenzo E, Schneider N, Cobb KM, Franks PJS, and others (2008) North Pacific Gyre Oscillation links ocean climate and ecosystem change. Geophys Res Lett 35: L08607, doi:10.1029/2007GL032838

Dietrich KS, Fitzgerald SM (2010) Analysis of 2004-2007 vessel-specific seabird bycatch data in Alaska demersal longline fisheries. AFSC Processed Report No. 2010-04. Alaska Fisheries Science Center, NOAA, National Marine Fisheries Services, Seattle, Seattle, WA

Drew GS, Piatt JF (2005) North Pacific Pelagic Seabird Database (NPPSD): compiling datasets and creating an archive, accessible database, and pelagic seabird atlas. Final report for the North Pacific Marine Research Institute. US Geological Survey, Anchorage, AK

> Drew GS, Dragoo DE, Renner M, Piatt JF (2010) At-sea observations of marine birds and their habitats before and after the 2008 eruption of Kasatochi Volcano, Alaska. Arct Antarct Alp Res 42:325-334

Fisher J (1952) The Fulmar. Collins, London

- Friedman JH (1991) Multivariate adaptive regression splines. Ann Stat 19:1-141

> Furness RW, Edwards AE, Oro D (2007) Influence of management practices and of scavenging seabirds on availability of fisheries discards to benthic scavengers. Mar Ecol Prog Ser 350:235-244

Garthe S, Scherp B (2003) Utilization of discards and offal from commercial fisheries by seabirds in the Baltic Sea. ICES J Mar Sci 60:980-989

GRASS Development Team (2009) Geographic Resources Analysis Support System (GRASS GIS) Software. Available at grass.osgeo.org

Grebmeier JM, Overland JE, Moore SE, Farley EV and others (2006) A major ecosystem shift in the northern Bering Sea. Science 311:1461-1464

Hastie TJ, Tibshirani RJ, Friedman J (2009) The elements of statistical learning. Springer, New York, NY

Hatch SA (1987) Adult survival and productivity of northern fulmars in Alaska. Condor 89:685-696

Hatch SA (1989) Diurnal and seasonal patterns of colony attendance in the northern fulmar, Fulmarus glacialis in Alaska. Can Field Nat 103:248-260

Hatch SA (1993) Ecology and population status of northern fulmars Fulmarus glacialis in the North Pacific. In: Vermeer K, Briggs KT, Morgan KH, Siegel-Causey D (eds) The status, ecology, and conservation of marine birds of the North Pacific. Canadian Wildlife Service Special Publication, Ottawa, p 82-91

Hatch SA, Nettleship DN (1998) Northern fulmar (Fulmarus glacialis). In: Poole A (ed) The birds of North America online. The birds of North America, Philadelphia, PA, p 1-32

- Hatch SA, Gill VA, Mulcahy DM (2010) Individual and colony-specific wintering areas of Pacific northern fulmars (Fulmarus glacialis). Can J Fish Aquat Sci 67: $386-400$

Huettmann F, Diamond AW (2001) Seabird colony locations and environmental determination of seabird distribution: a spatially explicit breeding seabird model for the Northwest Atlantic. Ecol Model 141:261-298

Hunt GL Jr, Baduini C, Jahncke J (2002a) Diets of shorttailed shearwaters in the southeastern Bering Sea. DeepSea Res II 49:6147-6156

Hunt GL Jr, Stabeno PJ, Walters G, Sinclair E, Brodeur RD, Napp JM, Bond NA (2002b) Climate change and control of the southeastern Bering Sea pelagic ecosystem. DeepSea Res II 49:5821-5853

> Hunt GL Jr, Drew GS, Jahncke J, Piatt JF (2005) Prey consumption and energy transfer by marine birds in the Gulf of Alaska. Deep-Sea Res II 52:781-797

Hunt GL Jr, Stabeno PJ, Storm S, Napp JM (2008) Patterns of spatial and temporal variation in the marine ecosystem of the southeastern Bering Sea, with special reference to the Pribilof Domain. Deep-Sea Res II 55:1919-1944

> Hunt GL Jr, Coyle KO, Eisner LB, Farley EV and others (2011) Climate impacts on eastern Bering Sea foodwebs: a synthesis of new data and an assessment of the oscillating control hypothesis. ICES J Mar Sci 68:1230-1243

Hyrenbach KD (2001) Albatross response to survey vessels: implications for studies of the distribution, abundance, and prey consumption of seabird populations. Mar Ecol Prog Ser 212:283-295

IPCC (2007) Summary for policymakers. In: Solomon S, Quin D, Manning M, Chen Z, Marquis M, Averyt KB, Tignor M, Miller HL (eds) Climate change 2007: the physical science basis. Contribution of working group I to the 4th assessment report of the intergovernmental panel on climate change. Cambridge University Press, New York, NY, p 1-18

IUCN (2001) IUCN Red list of threatened species - 2001 categories \& criteria (version 3.1). International Union for Conservation of Nature and Natural Resources, Gland

Jahncke J, Coyle KO, Hunt GL Jr (2005a) Seabird distribution, abundance and diets in the eastern and central Aleutian Islands. Fish Oceanogr 14(Suppl 1):160-177

Jahncke J, Coyle KO, Zeeman SI, Kachel NB, Hunt GL Jr (2005b) Distribution of foraging shearwaters relative to inner front of SE Bering Sea. Mar Ecol Prog Ser 305: 219-233

> Jahncke J, Vlietstra LS, Decker MB, Hunt GL Jr (2008) Atsea distributions of marine birds around the Pribilof Islands: a multi-year comparison of temporal and spatial patterns. Deep-Sea Res II 55:1809-1826

Jenouvrier S, Barbraud C, Weimerskirch H (2003) Effects of climate variability on the temporal population dynamics 
of southern fulmars. J Anim Ecol 72:576-587

Jones OR, Gaillard JM, Tuljapurkar S, Alho JS and others (2008) Senescence rates are determined by ranking on the fast-slow life-history continuum. Ecol Lett 11:664-673

- Kinder TH, Hunt GL Jr, Schneider DC, Schumacher JD (1983) Correlations between seabirds and oceanic fronts around the Pribilof Islands, Alaska. Estuar Coast Shelf Sci 16:309-310

Knudby A, Brenning A, LeDrew E (2010) New approaches to modelling fish-habitat relationships. Ecol Model 221: 503-511

Ladd C, Jahncke J, Hunt GL Jr, Coyle KO, Stabeno PJ (2005) Hydrographic features and seabird foraging in Aleutian passes. Fish Oceanogr 14(Suppl 1):178-195

> Lewison R, Crowder LB (2003) Estimating fishery bycatch and effects on a vulnerable seabird population. Ecol Appl 13:743-753

Liaw A, Wiener M (2002) Classification and regression by randomforest. R News 2:18-22

Marmion M, Luoto M, Heikkinen RK, Thuiller W (2009) The performance of state-of-the-art modelling techniques depends on geographical distribution of species. Ecol Model 220:3512-3520

McSorley CA, Dean BJ, Webb A, Reid JB (2006) Extending the boundaries of seabird breeding colony protected areas into the marine environment. In: Boere GC, Galbraith CA, Stroud DA (eds) Waterbirds around the world. The Stationery Office, Edinburgh, p 752-753

Melvin EF, Parrish JK (eds) (2001) Seabird bycatch: trends, roadblocks, and solutions. University of Alaska Sea Grant, Fairbanks, AK

Melvin EF, Parrish JK, Dietrich KS, Hamel OS (2001) Solutions to seabird bycatch in Alaska's demersal longline fisheries. Washington Sea Grant Program, Seattle, WA

Melvin EF, Dietrich K, Van Wormer K, Geernaert T (2004) Distribution of seabirds on Alaskan longline fishing grounds: 2002 data report. Washington Sea Grant Program, Seattle, WA

Migratory Bird Management (2010) North Pacific seabird colony database - computer database and colony status record archives. US Fish and Wildlife Service report, Available at alaska.fws.gov/mbsp/mbm/northpacificseabirds/colonies/default.htm

Montevecchi WA (2002) Interactions between fisheries and seabirds. In: Schreiber EA, Burger J (eds) Biology of marine birds. CRC Press, Boca Raton, FL, p 527-557

Moore JE, Wallace BP, Lewison RL, Žydelis R, Cox TM, Crowder LB (2009) A review of marine mammal, sea turtle and seabird bycatch in USA fisheries and the role of policy in shaping management. Mar Policy 33:435-451

Mueter FJ, Litzow MA (2008) Sea ice retreat alters the biogeography of the Bering Sea continental shelf. Ecol Appl 18:309-320

Neteler M, Mitasova H (2008) Open Source GIS: A GRASS GIS approach, 3rd edn. Springer, New York, NY

NMFS (2004) Final programmatic supplemental environmental impact statement for the Alaska groundfish fisheries. National Marine Fisheries Service, Alaska Region, Juneau, AK

NMFS (2006) Summary of seabird bycatch in Alaskan groundfish fisheries, 1993 through 2004. National Marine Fisheries Service, Alaska Fisheries Science Center. Available at www.afsc.noaa.gov/REFM/REEM/Seabirds/ Default.php

Oppel S, Meirinho A, Ramírez I, Gardner B, O'Connell AF,
Miller PI, Louzao M (2012) Comparison of five modelling techniques to predict the spatial distribution and abundance of seabirds. Biol Conserv 156:94-104

Orensanz J, Ernst B, Armstrong D, Stabeno P, Livingston P (2005) Contraction of the geographic range of distribution of snow crab (Chionoecetes opilio) in the eastern Bering Sea: an environmental ratchet? CCOFI Rep 45: 65-79

> Overland JE, Stabeno PJ (2004) Is the climate of the Bering Sea warming and affecting the ecosystem? Eos Trans Am Geophys Union 85:309-316, doi:10.1029/2004EO330001

Phillips RA, Petersen MK, Lilliendahl K, Solmundsson J, Hamer KC, Camphuysen CJ, Zonfrillo B (1999) Diet of the northern fulmar Fulmarus glacialis: reliance on commercial fisheries? Mar Biol 135:159-170

Piatt JF, Wetzel J, Bell K, DeGange AR and others (2006) Predictable hotspots and foraging habitat of the endangered short-tailed albatross (Phoebastria albatrus) in the North Pacific: implications for conservation. Deep-Sea Res II 53:387-398

R Development Core Team (2011) R: a language and environment for statistical computing. R Foundation for Statistical Computing, Vienna

Renner M, Hunt GL Jr, Piatt JF, Byrd GV (2008) Seasonal and distribution patterns of seabirds along the Aleutian Archipelago. Mar Ecol Prog Ser 357:301-311

> Skov H, Durinck J (2001) Seabird attraction to fishing vessels is a local process. Mar Ecol Prog Ser 214:289-298

Spear LB, Nur N, Ainley DG (1992) Estimating absolute densities of flying seabirds using analyses of relative movement. Auk 109:385-389

Spear LB, Ainley DG, Nur N, Howell SN (1995) Population size and factors affecting at-sea distributions of four endangered procellariids in the tropical Pacific. Condor 97:613-638

Springer AM, Piatt JF, Shuntov V, Van Vliet GB, Vladimirov V, Kuzin A, Perlov A (1999) Marine birds and mammals of the Pacific Subarctic Gyres. Prog Oceanogr 43:443-487

Stabeno PJ, Overland JE (2001) The Bering Sea shifts toward an earlier spring transition. Eos Trans Am Geophys Union 82:317-321, doi:10.1029/01EO00185

Stabeno PJ, Bond NA, Kachel N, Salo SA, Schumacher JD (2001) On the temporal variability of the physical environment over the south-eastern Bering Sea. Fish Oceanogr 10:81-98

Sydeman WJ, Ann Thompson S, Santora JA, Henry MF, Morgan KH (2010) Macro-ecology of plankton-seabird associations in the North Pacific Ocean. J Plankton Res 32:1697-1713

Tasker ML, Jones PH, Dixon T, Blake BF (1984) Counting seabirds at sea from ships: a review of methods employed and a suggestion for a standardized approach. Auk 101: 567-577

Tasker ML, Camphuysen KCJ, Cooper J, Garthe S, Montevecchi WA, Blaber SJM (2000) The impacts of fishing on marine birds. ICES J Mar Sci 57:531-547

Thompson PM, Ollason JC (2001) Lagged effects of ocean climate change on fulmar population dynamics. Nature 413:417-420

Trites AW, Miller AJ, Maschner HDG, Alexander MA and others (2007) Bottom-up forcing and the decline of Steller sea lions in Alaska: assessing the ocean climate hypothesis. Fish Oceanogr 16:46-67

Tuck GN, Polacheck T, Croxall JP, Weimerskirch H (2001) Modelling the impact of fishery by-catches on albatross 
populations. J Appl Ecol 38:1182-1196

van der Meer J, Camphuysen CJ (1996) Effect of observer differences on abundance estimates of seabirds from ship-based strip transect surveys. Ibis 138:433-437

van der Meer J, Leopold MF (1995) Assessing the population size of the European storm petrel (Hydrobates pelagicus) using spatial autocorrelation between counts from segments of criss-cross ship transects. ICES J Mar Sci 52: 809-818

van Franeker JA (1994) A comparison of methods for counting seabirds at sea in the Southern Ocean. J Field Ornithol 65:96-108

Ver Hoef JM, Boveng PL (2007) Quasi-Poisson vs. negative binomial regression: How should we model overdispersed count data? Ecology 88:2766-2772

Weimerskirch H, Jouventin P (1987) Population dynamics of

Editorial responsibility: Hans Heinrich Janssen,

Oldendorf/Luhe, Germany the wandering albatross, Diomedea exulans, of the Crozet Islands: causes and consequences of the population decline. Oikos 49:315-322

> Weimerskirch H, Chastel O, Cherel Y, Henden JA, Tveraa T (2001) Nest attendance and foraging movements of northern fulmars rearing chicks at Bjørnøya Barents Sea. Polar Biol 24:83-88

Wood JD (1996) The geomorphological characterisation of digital elevation models. $\mathrm{PhD}$ thesis, University of Leicester

Wood SN (2000) Modelling and smoothing parameter estimation with multiple quadratic penalties. J R Stat Soc B 62:413-428

Wood SN (2011) Fast stable restricted maximum likelihood and marginal likelihood estimation of semiparametric generalized linear models. J R Stat Soc B 73:3-36

Submitted: September 2, 2011; Accepted: March 20, 2013

Proofs received from author(s): June 1, 2013 